\title{
Microtopographic Drivers of Vegetation Patterning in Blanket Peatlands Recovering from Erosion
}

\author{
A. Harris ${ }^{1 *} \odot$ and A. J. Baird ${ }^{2}$ \\ ${ }^{1}$ Department of Geography, School of Environment, Education and Development, The University of Manchester ALB, Oxford Road, \\ Manchester M13 9PL, UK; ${ }^{2}$ School of Geography, University of Leeds, Woodhouse Lane, Leeds LS2 9JT, UK
}

\begin{abstract}
Blanket peatlands are globally rare, and many have been severely eroded. Natural recovery and revegetation ('self-restoration') of bare peat surfaces are often observed but are poorly understood, thus hampering the ability to reliably predict how these ecosystems may respond to climatic change. We hypothesised that morphometric/topographicrelated microclimatic variables may be key controls on successional pathways and vegetation patterning in self-restoring blanket peatlands. We predicted the occurrence probability of four common peatland plant species (Calluna vulgaris, Eriophorum vaginatum, Eriophorum angustifolium, and Sphagnum spp.) using a digital surface model (DSM) generated from drone imagery at a pixel size of $20 \mathrm{~cm}$, a suite of variables derived from the DSM, and an ensemble learning method (random forests). All four species models provided accurate fine-scale
\end{abstract}

predictions of habitat suitability (accuracy $>90 \%$, area under curve (AUC) $>0.9$, recall and precision $>0.8$ ). Mean elevation (within a $1 \mathrm{~m}$ radius) was often the most influential variable. Topographic position, wind exposure, and the heterogeneity or ruggedness of the surrounding surface were also important for all models, whilst lightrelated variables and a wetness index were important in the Sphagnum model. Our approach can be used to improve prediction of future responses and sensitivities of peatland recovery to climatic changes and as a tool to identify areas of blanket peatlands that may self-restore successfully without management intervention.

Key words: natural revegetation; DSM; eroded peatland; restoration; drone; topography; random forest.

Received 7 June 2018; accepted 19 October 2018;

published online 18 December 2018

Electronic supplementary material: The online version of this article (https://doi.org/10.1007/s10021-018-0321-6) contains supplementary material, which is available to authorized users.

Author contributions AH designed the study, analysed the data, and wrote the paper; AJB conceived and helped design the study, contributed to the data analysis, and contributed to the writing of the paper.

*Corresponding author; e-mail: angela.harris@manchester.ac.uk

\section{ManusCRipt Highlights}

- We used a fine-scale digital surface model to investigate drivers of natural revegetation patterning.

- Few topographic variables were required to accurately predict species' presence.

- The results can be used to understand future change trajectories in eroded peatlands. 


\section{INTRODUCTION}

Blanket peatlands are globally rare ecosystems. They occur in disjunct oceanic and hyper-oceanic high-latitude regions where precipitation (mostly rainfall) is common throughout the year and maintains wet conditions at the soil surface so that peat-forming plants (principally Sphagnum mosses and the cotton grasses (Eriophorum spp.)) can establish (Lindsay 2010 Unpublished; Gallego-Sala and Prentice 2013). In such areas, peat may cover or cloak whole landscapes. Peat tends to build to greater depths in hillslope hollows, so that the landscape becomes 'softer' in appearance. Approximately $13 \%$ of the global stock of blanket peatlands $\left(\sim 15,759 \mathrm{~km}^{2}\right)$ occurs in the UK (Baird and others 2009), which is regarded as a type location' for these ecosystems (Lindsay 2010). Despite suggestions that blanket peatlands formed in response to forest clearance in the Neolithic and Bronze Age (for example, Tallis 1998), there is strong evidence they are also natural phenomena (Lawson and others 2007; Gallego-Sala and others 2016).

Using a simple static model, Gallego-Sala and Prentice (2013) concluded that the bioclimatic space or envelope of blanket peatlands will shrink under a range of projected future climates. They noted that this shifting of the bioclimatic space, whilst not necessarily leading to an immediate reduction in the area of blanket peatlands, will lessen their ecological resilience, making them more prone to degradation and erosion. Although blanket peatland erosion may become more common as the climate changes, it has been a feature of UK blanket peatlands for $100 \mathrm{~s}$ of years and was noted as long ago as the early nineteenth century (for example, Aiton 1882, cit. Bower 1962); predating the intensive human use of the uplands (in the UK) in which most blanket peatlands are found. Blanket peat erosion has been widely reported since then (see Bragg and Tallis 2001; Evans and Warburton 2005), and numerous authors have speculated on the causes of such erosion (for example, Bower 1962; Bowler and Bradshaw 1985; Bragg and Tallis 2001; Clement 2005; Evans and Warburton 2005). The relative importance of the postulated causes may vary in different settings, and it is likely that erosion can have both natural and human-related origins.

According to Wishart and Warburton (2001) and Clement (2005), there are three classes of erosion landscape: (1) areas dominated by linear gullies, roughly parallel to each other, (2) areas where the gully network is dendritic, and (3) areas where the

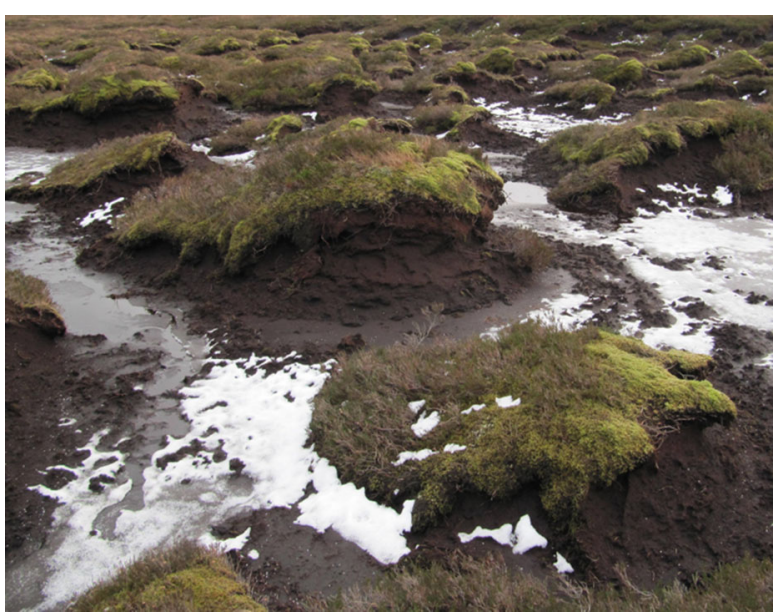

Figure 1. Example of a hagged peatland showing islands of un-eroded peat in a complex network of gullies, Ffynnon Eidda, Upper Conwy, North Wales. The hagg in the centre of the picture is $\sim 1 \mathrm{~m}$ high.

gully network is anastomosing. The last type of landscape is often referred to as a 'hagged peatland' (Figure 1) and usually occurs on lower-gradient areas such as hilltops and plateaus. The term 'hagg' or 'hag' is commonly used to describe the islands of, as yet, un-eroded peat found in anastomosing gully systems (for example, Bowler and Bradshaw 1985; Foulds and Warburton 2007; Figure 1).

Despite Gallego-Sala and Prentice's (2013) suggestion that blanket peatlands will, in the future, be prone to further degradation, it is notable that many erosion complexes, under current climates, are showing signs of recovery (Figure 2). Recovery involves the re-establishment of peat-forming vegetation on bare erosion surfaces, on areas where eroded peat has been deposited, and on areas of mineral ground exposed by the complete removal of peat in gully bottoms. However, whether revegetation is a temporary or more permanent phenomenon is contested. Wishart and Warburton (2001) appear to suggest that revegetation can only be temporary and that, once erosion has started, it will continue indefinitely. This view contrasts with Crowe and others (2008) who suggest that revegetating gullies may eventually fill with a combination of peat derived from gully walls (which tend to stabilise as material accumulates in the gully), material derived from upstream, and new peat formed in situ. Evans and Warburton (2007) review in more detail the factors involved in revegetation and suggest that it may be a natural part of an erosion-recovery cycle; however, they also note that whereas erosion has been studied in some 

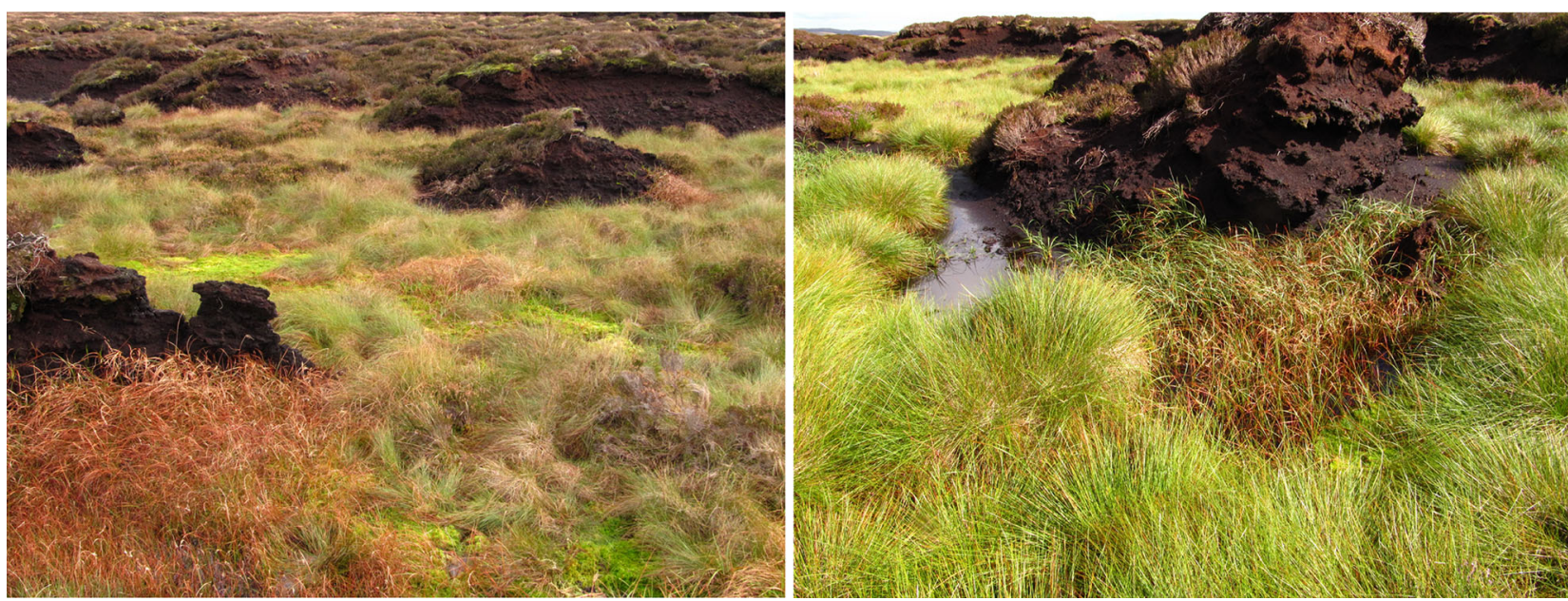

Figure 2. Photographs of part of the study site, showing peat haggs and the revegetating areas between them. Both photographs show areas of E. vaginatum and E. angustifolium, whereas small lawns of $S$. fallax can be seen in the left photograph. C. vulgaris is also evident on the haggs in both photographs. The haggs varied in height from $\sim 0.5$ to $\sim 2 \mathrm{~m}$.

detail, very little work has been done on revegetation and that our understanding of the mechanisms involved in revegetation remains limited.

Although erosion can cease and a peatland start to recover, from Gallego-Sala and Prentice's (2013) analysis it is not clear whether regeneration can continue over the coming decades as the climate changes and the bioclimatic envelope for blanket peatlands shrinks. To understand future trajectories of regeneration in blanket peatlands, it is necessary to understand the factors involved in the shift from erosion to revegetation so that a mechanistic understanding can be obtained. Such an understanding can be used to 'inform' and improve process-based models such as DigiBog, which have already been used to investigate the effect of drainage ditch construction and later blocking on peat growth and degradation (Young and others 2017).

Palaeoecological, experimental, and spatial correlative approaches could all be used to study peatland regeneration. The last of these involves looking at areas undergoing natural revegetation and evaluating, from detailed field survey or remote sensing imagery, the topographic and morphological settings characteristic of different successional pathways. This approach considers only a snapshot in time, but in areas in which revegetation is well established it can be useful for developing a process-based understanding of what drives change in these systems and the key factors involved in recovery. A notable example of such a study is Evans and others (2005), who undertook a detailed field-based study to investigate links be- tween the type of revegetation and the morphometric characteristics of the gullies in which revegetation had occurred. Using cluster and ordination analysis, they found that gully floor slope and gully width were particularly influential factors.

Whilst terrestrial surveys such as the one undertaken by Evans and others (2005) can provide detailed information, they require extensive ground-based measurements, which are time-consuming and difficult to collect. Since the study of Evans and others (2005), there has been an explosion in the use of drone-based remote sensing to obtain high-spatial-resolution data on vegetation composition and microtopography of a wide range of environments, including peatlands (for example, Lehmann and others 2016; Simpson and others 2016; Lovitt and others 2017; Rahman and others 2017). Using structure from motion (SfM) techniques, an array of detailed morphological characteristics can easily be obtained from drone imagery. In the study, we report herein, we used this approach to establish the factors that control the distribution of vegetation in a self-restoring hagged peatland. We hypothesised that morphometric/topographic and related microclimatic variables may be key controls on vegetation patterning and thus successional pathways in such self-restoring systems. Specifically, our objectives were to (1) obtain an accurate prediction of the current occurrence of key species across a hagged peatland, using only fine-scale morphometric and topographic variables, and (2) quantify the relative importance of each of 
the variables and their marginal effects on the prediction of a species' probability of occurrence.

\section{Methodology}

\section{Study Area and Target Species}

The study site is an area of hagged peatland near Ffynnon Eidda in the upper Conwy catchment in North Wales, UK, owned and managed by The National Trust (a UK conservation charity). It is approximately $500 \mathrm{~m}$ above mean sea level on a gently sloping hilltop. Limited climate data exist for the area, but automatic weather station records from March 2011 to March 2015 suggest an annual average rainfall of $\sim 2100 \mathrm{~mm}$ and an annual average air temperature of $7.2^{\circ} \mathrm{C}$ (Green and others 2017). Snow is common during winter and early spring but rarely lies for more than a few days before thawing. Air frosts are also common during winter and early spring, but temperatures below $5^{\circ} \mathrm{C}$ are unusual. Fog is frequent, and in summer daily high air temperatures do not usually exceed $20^{\circ} \mathrm{C}$. The peat at the site is underlain by Cambrian mudstones and siltstones (Lynas 1973), and reaches maximal thicknesses of between 2 and $4 \mathrm{~m}$. Based on a walkover assessment of the site, four dominant species/plant groups were selected for mapping: (1) Calluna vulgaris L. (Common Heather or Ling), (2) Eriophorum vaginatum L. (Hare's Tail Cotton Grass), (3) Eriophorum angustifolium Honck. (Common Cotton Grass), and (4) Sphagnum spp. (Bog Mosses-those investigated comprised almost exclusively $S$. fallax (Klinggr.) Klinggr. and S. cuspidatum Ehrh. ex Hoffm.). Calluna was selected because it was common on the uneroded haggs, whereas the other three were the most frequently encountered species in the revegetating areas between the haggs.

A subsection of the hagged portion of the peatland $\left(0.03 \mathrm{~km}^{2}\right)$ was selected for detailed analysis (see Section "Digital Surface Model from Drone Imagery"). The selected area contained a complex of haggs, bare peat, and vegetation (Figure 3 ) and is like many hagged landscapes seen across a range of blanket peatlands in the UK (see Evans and Warburton 2007). The region also corresponds to the anastomosing gully network category of erosion proposed by Wishart and Warburton (2001) and Clement (2005) (see Introduction).

\section{Digital Surface Model from Drone Imagery}

Image data were acquired and processed by a thirdparty drone operator in July 2012. The data were collected using a SenseFly swingletCam fixed wing drone and consumer-grade digital camera (Canon IXUS $220 \mathrm{HS}, 12.1$ megapixel resolution). Due to the wind and lighting conditions at the time of data collection, multiple flyovers $(>100)$ were undertaken ( $\sim 650$ m altitude, WGS84) covering a range of orientations to ensure sufficient image overlap (Table S1). The flight pattern resulted in the collection of 1,096 images covering an area of $0.3 \mathrm{~km}^{2}$ with an average ground sampling distance (GSD) of $2.46 \mathrm{~cm}$.

The images were synchronised using onboard GPS positional information and the triggering time recorded for each image. The imagery was pro-
A

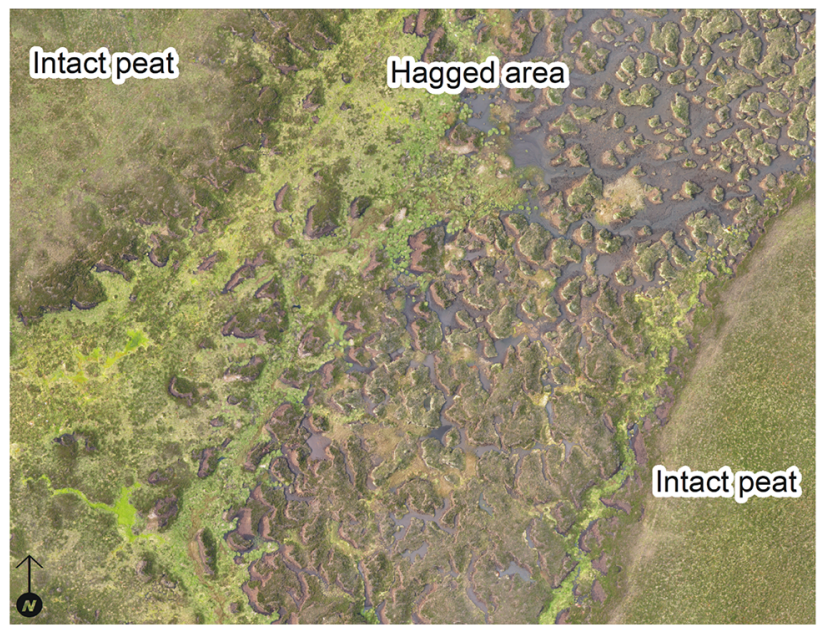

B

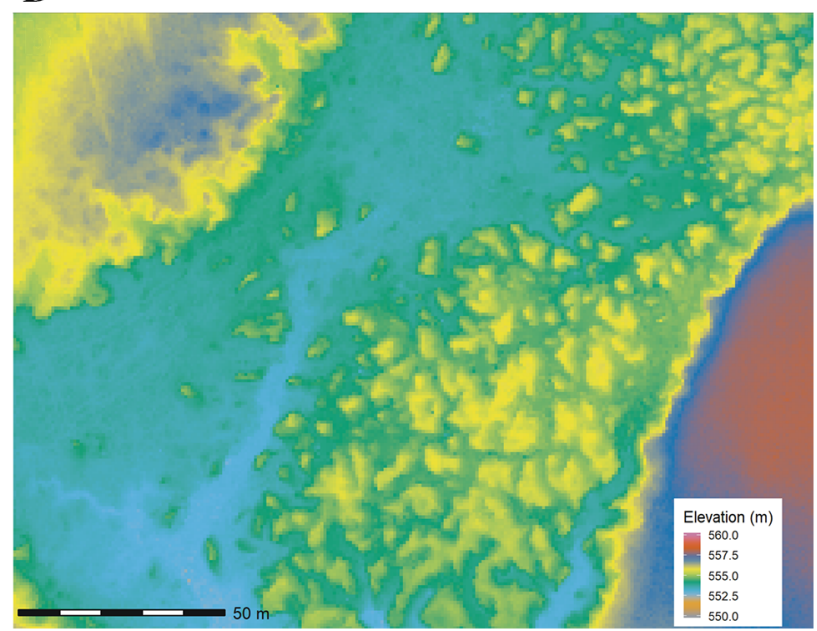

Figure 3. (A) Orthomosaic of the study area ( $2.5 \mathrm{~cm} \mathrm{GSD})$ and (B) corresponding digital surface model (DSM; $20 \mathrm{~cm}$ GSD). 
cessed using Pix4Dmapper Pro software (version 2.0.1000, Lausanne, Switzerland) to generate a digital surface model (DSM) and a digital orthomosaic. Ground control points (GCPs) were not obtained at the time of data collection, and thus, the geolocalisation process was dependent on the GPS measurements provided by the drone (Table S1). To minimise geolocation errors caused by the absence of GCPs during the creation of the DSM and orthomosaic, we subsequently co-registered both datasets to a vertical aerial photograph (23 August 2015; GSD $25 \mathrm{~cm}$ ) obtained from the EDINA Aerial Digimap Service (http://digimap.ed ina.ac.uk). The data provider, Getmapping, states that the geolocation root mean square error (RMSE) of the aerial imagery is $\pm 0.75 \mathrm{~m}$. To maximise the accuracy of the co-registration process, only a subsection of the hagged portion of the peatland $\left(0.03 \mathrm{~km}^{2}\right)$ was co-registered and used for subsequent analyses. No clearly observable changes in the surface patterning of this region were observed between the 2012 (drone survey) and 2015 (aerial survey) imagery. ENVI 5.4 (Harris Geospatial Solutions) was used to automatically generate 210 spatially distributed tie points between the vertical aerial photograph and the drone data. A bilinear interpolation algorithm and nearest-neighbour resampling were applied to co-register the imagery (RMSE $\pm 0.74 \mathrm{~cm}$ ).

We assessed the vertical accuracy and precision of the DSM by comparing it to a DSM generated from LiDAR data provided by the National Trust (see Williamson and others 2017). The drone DSM was resampled to a spatial resolution (the size of the pixel) of $50 \mathrm{~cm}$ to match the LiDAR DSM, and vertical agreement was assessed by comparing elevations between the two datasets. Tests for normality of the residuals (vertical errors between drone and LiDAR-based DSMs) revealed a non- normal distribution (data not shown); consequently, the median and normalised median absolute deviation (NMAD) were calculated as robust measures of vertical agreement assessment (Höhle and Höhle, 2009); we also calculated the RMSE. Table 1 and Figure S1 provide the results of the vertical agreement assessment. Although the results suggest poor vertical accuracy due to the absence of GCPs during processing, precision (as indicated by the NMAD) was high $(\sim 11 \mathrm{~cm})$ and thus the DSM was deemed fit for purpose, although stated elevation values should be interpreted as relative rather than absolute.

Following the vertical accuracy assessment, the drone DSM was resampled from its original $\sim 2.5 \mathrm{~cm}$ GSD to a resolution of $20 \mathrm{~cm}$ as an appropriate resolution for a region where the characteristic dimensions of microtopographic features are of the order of $\sim 10^{0}-10^{1} \mathrm{~m}$. A suite of morphometric and topographic metrics was obtained from the DSM. These variables were taken as proxies for direct environmental variables (Table 2), to explore the controlling environmental variables influencing the distribution of each of the chosen key species/plant groups. Terrain-related gradients are highly correlated with mesoscale climatic and geomorphological factors (Kumar and others 1997), such as wind and sun exposure and peat depth, that are often expensive and difficult to measure in fine detail over large areas. Consequently, there are distinct advantages in using variables that can be derived entirely from elevation data. Elevation was extracted directly from the generated DSM. All other explanatory variables were computed based on the DSM (Figure 3B) using the RSAGA package in R (Brenning 2008) and extracted for each sample location to generate random forest (RF) models (see section "Random Forest Modelling").

Table 1. Vertical Agreement Assessment of the Drone and LiDAR-based DSMs

\begin{tabular}{|c|c|c|}
\hline Accuracy measure & Notational expression & $\begin{array}{l}\text { Value } \\
\text { (m) }\end{array}$ \\
\hline Median (50\% quantile) & $\begin{array}{l}m_{\Delta h} \\
\quad \text { where } \Delta h \text { is the difference in height between the two DSMs }\end{array}$ & 55.98 \\
\hline $\begin{array}{l}\text { Normalised median absolute devia- } \\
\text { tion (NMAD) }\end{array}$ & $1.4826 \operatorname{median}_{j}\left(\left|\Delta h_{j}-m_{\Delta h}\right|\right)$ & 0.11 \\
\hline Root mean square error (RMSE) & $\begin{array}{l}\sqrt{\overline{\left(p-o^{2}\right)}} \\
\text { where } p \text { is the predicted values (drone DSM) and } o \text { is the observed } \\
\text { values (LiDAR DSM) }\end{array}$ & 55.97 \\
\hline
\end{tabular}


Table 2. List of Morphometric and Topographic Variables Derived from the Digital Surface Model (DSM)

\begin{tabular}{|c|c|c|c|c|}
\hline & $\begin{array}{l}\text { Predictor } \\
\text { Variable }\end{array}$ & Abbreviation & Description & Formula/Units \\
\hline \multirow{4}{*}{$\begin{array}{l}\text { Primary } \\
\text { attri- } \\
\text { butes }\end{array}$} & Elevation & ELEV & Mean elevation within a $1 \mathrm{~m}$ radius & Metres \\
\hline & Slope & SLP & $\begin{array}{l}\text { Steepest slope angle within a } 1 \mathrm{~m} \\
\text { radius }\end{array}$ & Degrees \\
\hline & $\begin{array}{l}\text { Profile curva- } \\
\text { ture }\end{array}$ & VCU & $\begin{array}{l}\text { Direction of the steepest slope. Af- } \\
\text { fects the acceleration or decelera- } \\
\text { tion of water (Zevenbergen and } \\
\text { Thorne, 1987) }\end{array}$ & Degrees \\
\hline & Plan curvature & $\mathrm{HCU}$ & $\begin{array}{l}\text { Horizontal curvature intersecting } \\
\text { with the } x-y \text { surface plane. Affects } \\
\text { the convergence or divergence of } \\
\text { water (Zevenbergen and Thorne, } \\
\text { 1987) }\end{array}$ & Degrees \\
\hline \multirow[t]{5}{*}{$\begin{array}{l}\text { Secondary } \\
\text { attri- } \\
\text { butes }\end{array}$} & $\begin{array}{l}\text { Morphometric } \\
\text { protection } \\
\text { index }(1,4)^{*}\end{array}$ & MPI & $\begin{array}{l}\text { Measure of exposure/protection of a } \\
\text { point from the surrounding relief. } \\
\text { Calculated by analysing the de- } \\
\text { gree to which the surrounding } \\
\text { relief (windows with } n \text { metres ra- } \\
\text { dii) protects the given cell (Yo- } \\
\text { koyama and others 2002) }\end{array}$ & $\begin{array}{l}\text { No unit } \\
\text { Value is negative when the point } \\
\text { is not protected and positive when } \\
\text { it is }\end{array}$ \\
\hline & $\begin{array}{l}\text { Topographic } \\
\text { position in- } \\
\operatorname{dex}(1,4)^{*}\end{array}$ & TPI & $\begin{array}{l}\text { Difference between elevation of the } \\
\text { cell and the mean of the elevation } \\
\text { in surrounding cells (windows } \\
\text { with } n \text { metres radii), calculated by } \\
\text { dividing the elevation difference } \\
\text { by its standard deviation (Guisan } \\
\text { and others 1999) }\end{array}$ & $\begin{array}{l}\text { No unit } \\
\text { Value is positive when the point is } \\
\text { higher than its surroundings, zero } \\
\text { when in a flat area or mid slope } \\
\text { and negative when lower than its } \\
\text { surroundings }\end{array}$ \\
\hline & $\begin{array}{l}\text { Terrain } \\
\quad \text { ruggedness } \\
\text { index }(1,4)^{*}\end{array}$ & TRI & $\begin{array}{l}\text { A measure of terrain complexity/ } \\
\text { heterogeneity. It calculates the } \\
\text { sum change in elevation between } \\
\text { a grid cell and its neighbouring } \\
\text { grid cells. The radius of the mov- } \\
\text { ing window determines how } \\
\text { many cells are used to calculate } \\
\text { the change in elevation (Riley and } \\
\text { others 1999) }\end{array}$ & $\begin{array}{l}\text { Metres } \\
\text { Value is always } \geq 0 \mathrm{~m} \text {, where } 0 \\
\text { represents the minimum rough- } \\
\text { ness }\end{array}$ \\
\hline & $\begin{array}{l}\text { Vector rugged- } \\
\text { ness mea- } \\
\text { sure }(1,4)^{*}\end{array}$ & VRM & $\begin{array}{l}\text { A measure of terrain complex- } \\
\text { ity/variance that captures vari- } \\
\text { ability in slope and aspect in a } \\
\text { single measure. Ruggedness is } \\
\text { measured as the dispersion of } \\
\text { vectors orthogonal to the surface } \\
\text { within a specific neighbourhood. } \\
\text { The radius of the moving window } \\
\text { determines how many cells are } \\
\text { used to calculate the change in } \\
\text { ruggedness }\end{array}$ & $\begin{array}{l}\text { No unit } \\
\text { Value is zero when there is no } \\
\text { terrain elevation and } 1 \text { when } \\
\text { there is complete variation. Natu- } \\
\text { ral terrain has values between } 0 \\
\text { and } 0.4\end{array}$ \\
\hline & $\begin{array}{l}\text { Sky view fac- } \\
\text { tor }\end{array}$ & SVF & $\begin{array}{l}\text { The ratio of the radiation received } \\
\text { by a planar surface to the radia- } \\
\text { tion emitted by the entire hemi- } \\
\text { spheric environment (Böhner and } \\
\text { Antonic, 2009) }\end{array}$ & $\begin{array}{l}\text { No unit } \\
\text { Values range from } 1 \text { for com- } \\
\text { pletely unobstructed surfaces (for } \\
\text { example, horizontal surfaces, } \\
\text { peaks and ridges) to } 0 \text { for com- } \\
\text { pletely obstructed surfaces }\end{array}$ \\
\hline
\end{tabular}


Table 2. continued

\begin{tabular}{|c|c|c|c|}
\hline $\begin{array}{l}\text { Predictor } \\
\text { Variable }\end{array}$ & Abbreviation & Description & Formula/Units \\
\hline Visible sky & VIS & $\begin{array}{l}\text { The percentage of the unobstructed } \\
\text { hemisphere above a certain location }\end{array}$ & Percentage \\
\hline $\begin{array}{l}\text { SAGA } \\
\text { wetness } \\
\text { index }\end{array}$ & SWI & $\begin{array}{l}\text { A variant of the topographic wetness } \\
\text { index (TWI) for soil moisture pre- } \\
\text { diction that models potential areas of } \\
\text { water accumulation. SWI values in } \\
\text { flat areas are spread into larger } \\
\text { neighbourhoods compared with the } \\
\text { standard TWI calculation (Böhner } \\
\text { and others 2002) }\end{array}$ & $\begin{array}{l}\text { No unit } \\
\text { SWI }=\frac{a}{\ln S} \\
\text { where } a \text { is the specific catchment } \\
\text { area and } S \text { the slope }\end{array}$ \\
\hline $\begin{array}{l}\text { Wind } \\
\text { exposi- } \\
\text { tion in- } \\
\text { dex }\end{array}$ & WEI & $\begin{array}{l}\text { Calculates the average wind effect } \\
\text { across all directions using an angular } \\
\text { step (Böhner and Antonic, 2009) }\end{array}$ & $\begin{array}{l}\text { No unit } \\
\text { Values below } 1 \text { indicate wind- } \\
\text { shadowed areas whereas values } \\
\text { above } 1 \text { indicate areas exposed to } \\
\text { the wind }\end{array}$ \\
\hline $\begin{array}{l}\text { Direct } \\
\text { insola- } \\
\text { tion }\end{array}$ & DIR & $\begin{array}{l}\text { Potential incoming direct solar radia- } \\
\text { tion }\end{array}$ & $\begin{array}{l}\text { KWh m} ~_{-2} \\
\text { Computed over a 12-month per- } \\
\text { iod }\end{array}$ \\
\hline $\begin{array}{l}\text { Diffuse } \\
\text { insola- } \\
\text { tion }\end{array}$ & DIF & $\begin{array}{l}\text { Potential incoming diffuse solar radia- } \\
\text { tion }\end{array}$ & $\begin{array}{l}\text { KWh m }{ }^{-2} \\
\text { Computed over a 12-month per- } \\
\text { iod }\end{array}$ \\
\hline
\end{tabular}

*Morphometric/topographic variables calculated using variable radii. The lower radius is indicative of the conditions surrounding the immediate location, whereas the higher radius is indicative of broader microtopographic and microclimatic conditions.

\section{Species Data}

Plant species presence data were obtained directly from the orthomosaic. The high spatial resolution $(\sim 2.5 \mathrm{~cm})$ of the data, in combination with several onsite visits made in 2012 and 2013, meant that the four species selected could be manually identified from the imagery. The RF algorithm used to develop each species model requires both presence and absence data. Consequently, absence data for each species were generated from the presence points of the other identified species (Buechling and Tobalske 2011). A total of 4,281 independent presence locations, where it was clear that a species was visually dominant, were used to build the four species models (Table 3, Figure 4).

\section{Data Preparation}

To avoid negative bias, the data were randomly sampled so that the number of absences equalled the number of presence samples for each species. Local Moran's I statistic of spatial association and associated $z$-values (R package 'spdep', Bivand and Piras 2015) were used to test for the presence of spatial autocorrelation in each predictor variable. The resultant values suggested each variable had a random spatial pattern $(z$-values $<|1.96|)$ and

Table 3. Performance of Each Species Habitat Model

\begin{tabular}{lllll}
\hline & C. vulgaris & E. angustifolium & E. vaginatum & Sphagnum \\
\hline OOB error rate $(\%)$ & 7.02 & 7.02 & 8.49 & 6.65 \\
Recall* $^{*}$ & 0.91 & 0.95 & 0.94 & 0.97 \\
Precision* $_{\text {AUC* }}^{*}$ & 0.93 & 0.91 & 0.89 & 0.89 \\
Prevalence & 0.98 & 0.98 & 0.97 & 0.98 \\
Total no. observations & 0.5 & 0.5 & 0.5 & 0.5 \\
\end{tabular}

* Obtained from tenfold cross-validation.

The out-of-bag $(O O B)$ error rate, recall, precision, and the area under the ROC curve (AUC) are reported, together with the prevalence and total number of observations (20 cm $\times 20 \mathrm{~cm}$ grid square) used to train and validate each model. 


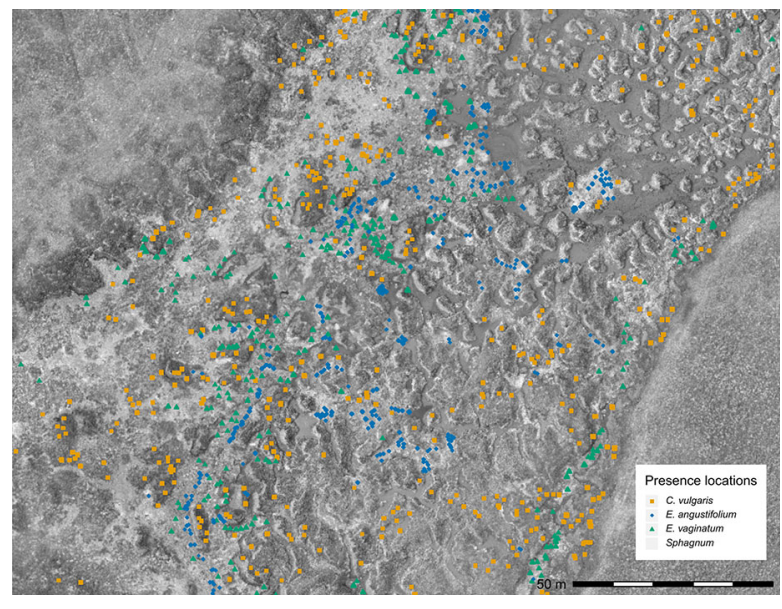

Figure 4. Presence locations used to develop each of the species models. A greyscale image of the orthophotograph is used as the background layer.

showed little evidence of spatial autocorrelation; thus, all variables were included in initial runs of the RF models.

\section{Random Forest Modelling}

We used the RF method (Breiman, 2001) to develop separate presence-absence models to predict the occurrence probabilities of each target species (i.e. one model per plant species/group) based on the morphometric and topographic variables derived from the DSM (Table 2; Figure 5). RF is a machine learning classification and regression tree method, which uses multiple randomised decision trees to determine the model output. The key strengths of RF are that it can capture complex and often nonlinear interactions and use large numbers of independent and often correlated variables without over-fitting (Breiman 2001; Liaw and Wiener 2002). In addition, RF provides measures of the importance of each input variable to the modelling process, which can prove valuable for exploratory ecological interpretation (Cutler and others 2007). RF has been used in a range of disciplines, including ecohydrological assessments (for example, Peters and others 2007) and the prediction of vegetation composition from remotely sensed imagery (for example, Chapman and others 2010).

The randomForest package in $\mathrm{R}$ (Liaw and Wiener 2002) was used to construct the RF models. For each model, two-thirds of the data were used for multiple tree growth. The remaining samples are known as out-of-bag (OOB) observations. At each node of each tree, the algorithm determined the explanatory variables (and the values of those variables) that optimise the differences between the presence and absence of a given species. The de-

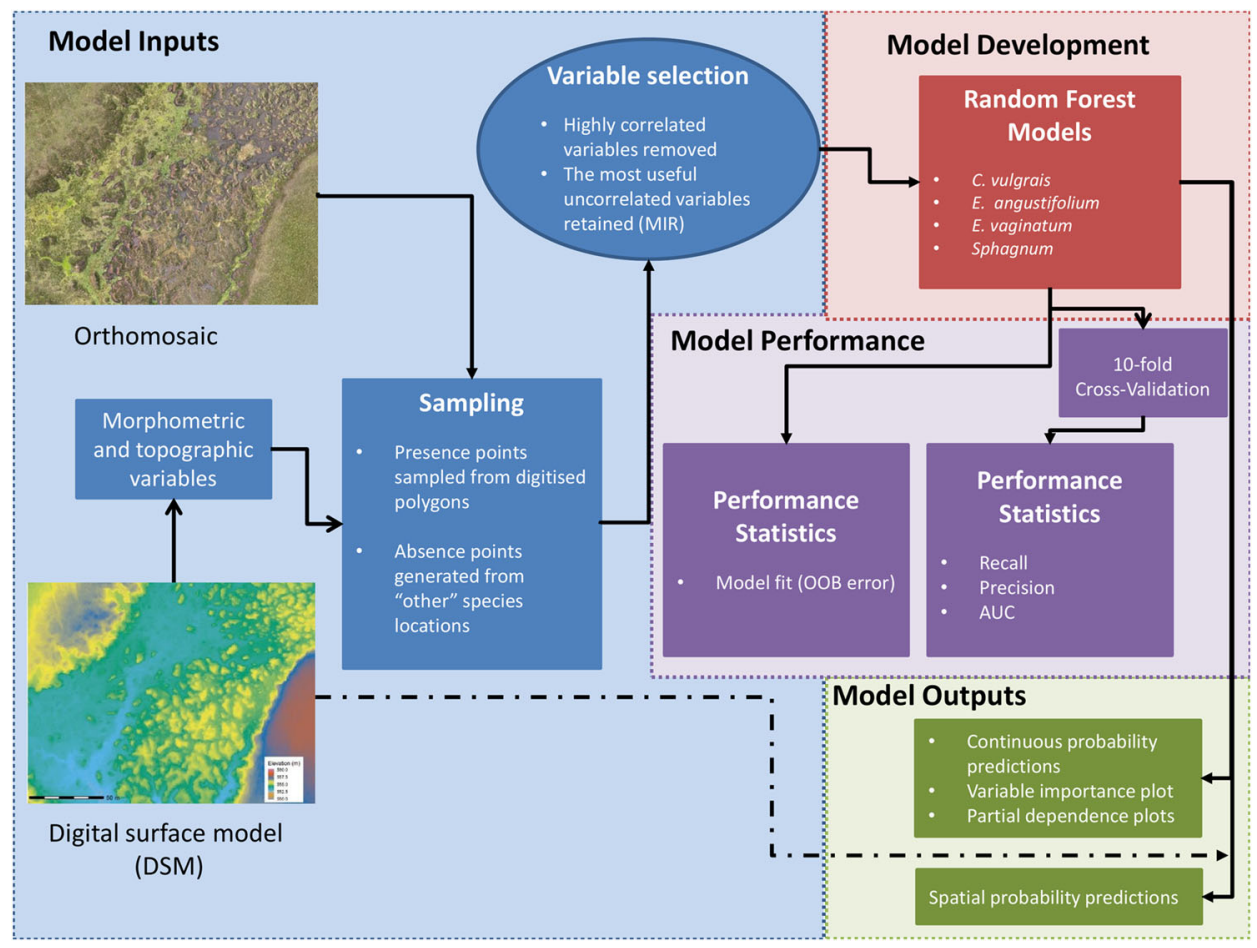

Figure 5. A generalised workflow of the random forest (RF) modelling process including model inputs, model development, model performance, and model outputs. 
fault value was used to determine the appropriate number of variables used to split the data at each node of each tree (mtry). Each tree was grown to the largest extent possible. When the trees were fully grown, they were used to predict the OOB observations. The number of trees to be grown was set to 500 per model based on the relationship between OOB error estimates and number of trees (data not shown). To classify an object based on its attributes, each tree is said to 'vote' for that class. The predicted class (i.e. presence/absence) of an observation was the class with most votes over all trees in the forest.

\section{Variable Selection and Variable Importance}

Although RF can utilise an extensive number of correlated predictor variables, parsimonious models including uncorrelated variables are more easily interpretable and may have increased predictive power (Murphy and others 2010). Consequently, we tested for collinearity amongst predictor variables and used the model improvement ratio (MIR; Evans and Cushman 2009) to select only the most useful uncorrelated variables to include in each RF model. The MIR is a ratio of the importance of a variable (the permuted variable importance measure) to the maximum model improvement score. The variables are put into subsets using MIR thresholds (0-1, in 0.1 increments). The optimal threshold, and thus selection of variables, is found where the number of retained variables and the model mean squared error (MSE) are both minimised and the percentage of variation explained is maximised (Murphy and others 2010). We used the rfUtilities package in R (Evans and Murphy 2016) to run the MIR for each species model.

The mean decrease in accuracy was used as a measure of the relative importance of each of the remaining predictor variables. The mean decrease in accuracy is calculated according to how much the prediction error increases when OOB data for that variable are permuted whilst all others are left unchanged (Liaw and Wiener 2002). The higher the mean decrease in accuracy, the more important the variable. As RF models are stochastic, we also tested for the stability of the variable importance by running each model 25 times and comparing the ranking of the top five variables for each model run.

\section{Model Outputs}

Each RF model was run to provide species probability predictions, predicted using a ratio of the RF majority votes matrix to create a probability distribution:

$$
P\left(c_{j}\right)=N_{c_{j}} / N_{t o t}
$$

where $P\left(c_{j}\right)$ is the probability of the occurrence class $c_{j}$ (i.e. presence or absence), $N_{c_{j}}$ is the number of trees classifying the species as occurrence class $c_{j}$, and $N_{t o t}$ is the number total number of trees in the random forest (i.e. 500).

A series of partial dependence plots (PDPs) was created to assess the dependence of the response variable (i.e. probability of species occurrence) on the most important morphological and topographic explanatory variables. PDPs summarise the effect of a given predictor variable on the probability of species occurrence after accounting for the average effect of all other variables. Partial dependence plots were created using the rfUtilities package in $\mathrm{R}$ (Evans and Murphy 2016) and are presented using a logit scale (due to the presence/absence classification) in relation to the probability for predicting the presence class. We used the raster package in $\mathrm{R}$ (Hijmans 2016) to make spatial model predictions from the final RF models.

\section{Model Performance}

The OOB error rate was used to determine model fit and the generalisation power of each model. To further assess the error in the prediction performance, we used tenfold cross-validation. The data for each species were split into ten subsets, with equal numbers of presence and absence data in each. For each species model, the RF model was fitted ten times, each time leaving out one of the subsets in the fitting, and predicting the left-out subset. The following threshold-dependent and threshold-independent performance metrics were obtained from the cross-validation predictions using the rms (Harrell Jr 2016) and caret (Kuhn and others 2015) packages in R:

(1) Recall-The proportion of observed presences correctly predicted ( $>50 \%$ of the tree votes). The higher the recall, the fewer the number of presence points that the algorithm will miss;

(2) Precision-The proportion of predicted presences that are observed to be present;

(3) Area under the receiver operating characteristic curve (AUC)-Illustrates the diagnostic ability of a binary classifier to correctly predict each class (i.e. presence-absence) as the discriminant threshold is varied. The AUC is the probability that the classifier will assign a higher score to a randomly chosen presence 
observation than a randomly chosen absence observation. The AUC value is not threshold dependent. A model with no better accuracy than chance has an AUC of 0.5, whereas a model with perfect accuracy has an AUC of 1 .

\section{RESUlts}

\section{Overall Performance}

The results of the performance tests for each model (Table 3) indicated strong predictive performance, with models reporting OOB error rates of between about 6 and $9 \%$ and AUC values greater than 0.9 . Recall and precision values were also very good $(>0.8)$ across all models (Table 3 ).

Figure 6 indicates the probability range associated with each of the predicted presence locations (correctly and incorrectly predicted), based on the cross-validation, and provides an indication of the strength of the occurrence predictions (Peters and others 2007). The total number of correct presence predictions was always greater than the number of incorrect presence predictions (i.e. false positives). For all models, the number of correct predictions was positively related to prediction probability. The number of false positives was always highest for locations with low predicted probability; thus, more care should be taken when interpreting spatial predictions of presence where prediction probabilities are low (Figure 7).

Multi-collinear analysis indicated that the morphometric protection index (4 m radius; MPI4), the topographic protection index (4 $\mathrm{m}$ radius; TPI4), and the sky view factor (SVF) showed evidence of correlation with other explanatory variables $(p=0.001)$ and thus were removed from further analyses. The $C$. vulgaris and E. angustifolium models utilised the least number of input variables (six out of 14), whereas the Sphagnum model used the most (Figure 8). Of the variables selected, elevation, topographic position, and ruggedness indices were consistently the most important. All models made use of indices calculated across different spatial extents (i.e. $1 \mathrm{~m}$ and $4 \mathrm{~m}$ radii). Variable importance was stable across repeat runs of the RF models (results not shown).

Partial dependence plots (PDPs) were explored to better understand the effects of the most important variables in each model (Figures 9, 10, 11, 12). Specifically, we used the PDPs to illustrate the marginal effect of the selected explanatory variable on the probability of species presence, whilst averaging out the effect of all other parameters.
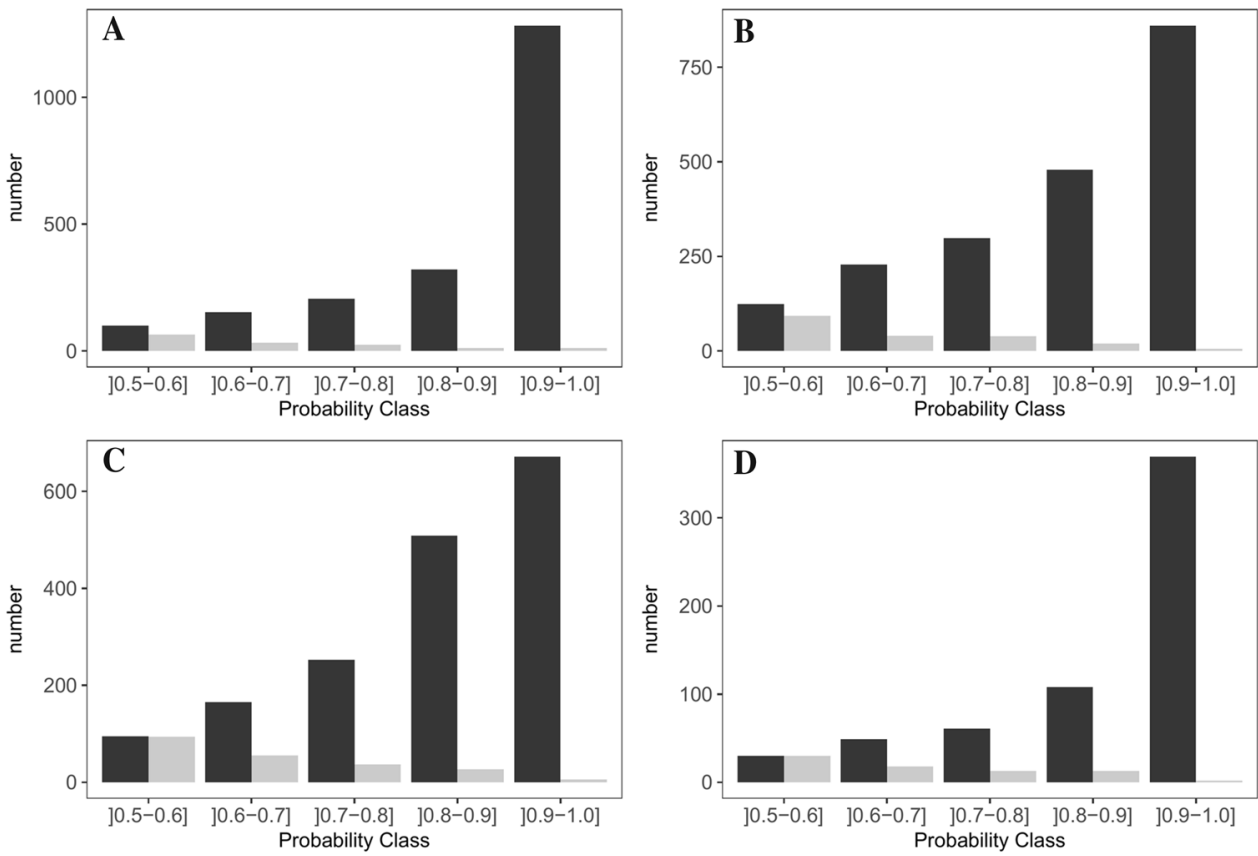

Correct Incorrect

Figure 6. Probability distributions of correct and incorrect presence predictions (i.e. false positives) for $\mathbf{A} C$. vulgaris; $\mathbf{B} E$. angustifolium; C E. vaginatum and D Sphagnum mosses 

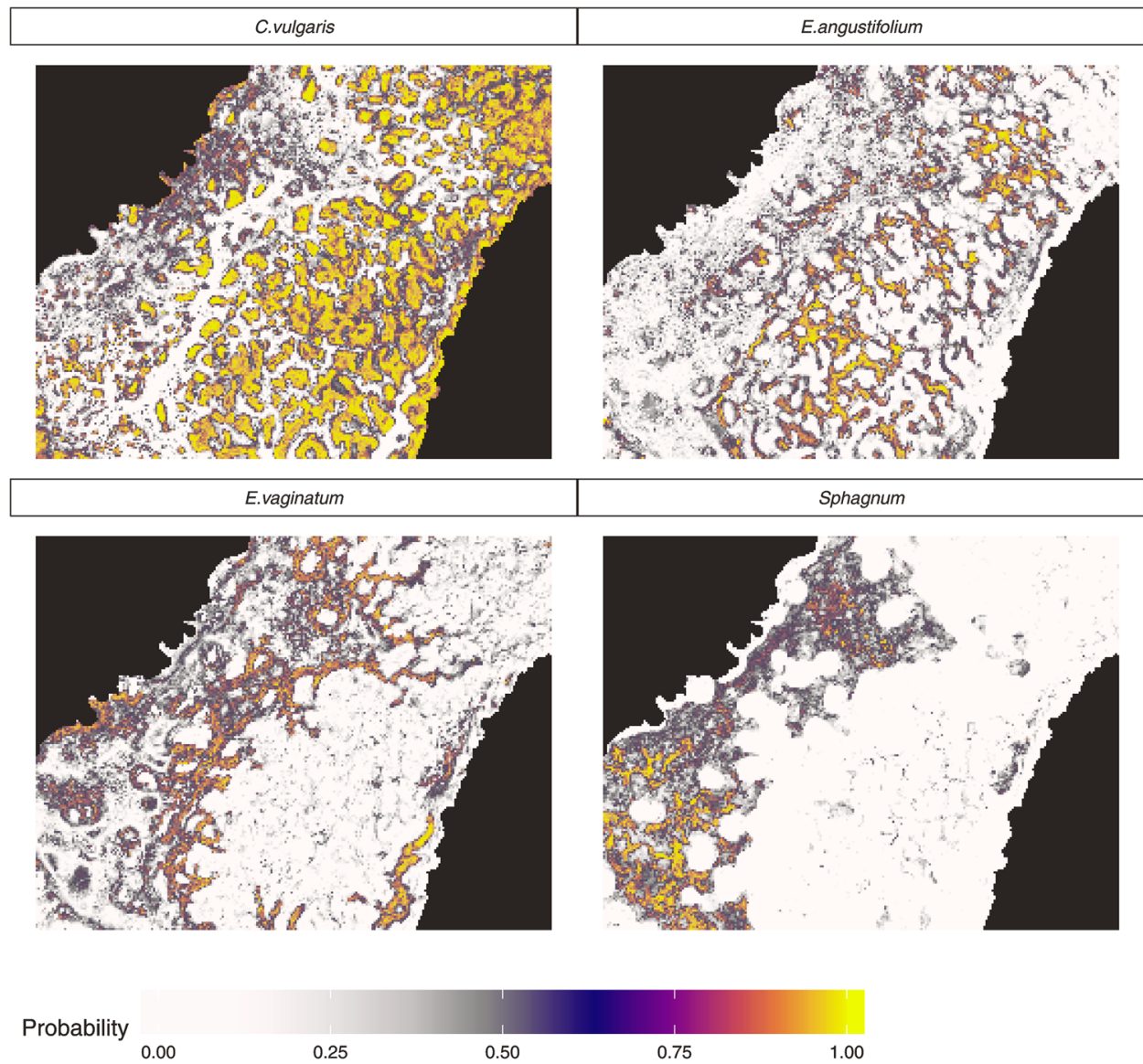

Figure 7. Spatial patterns of predicted probabilities of occurrence for each species. Areas of intact bog have been masked (in black)

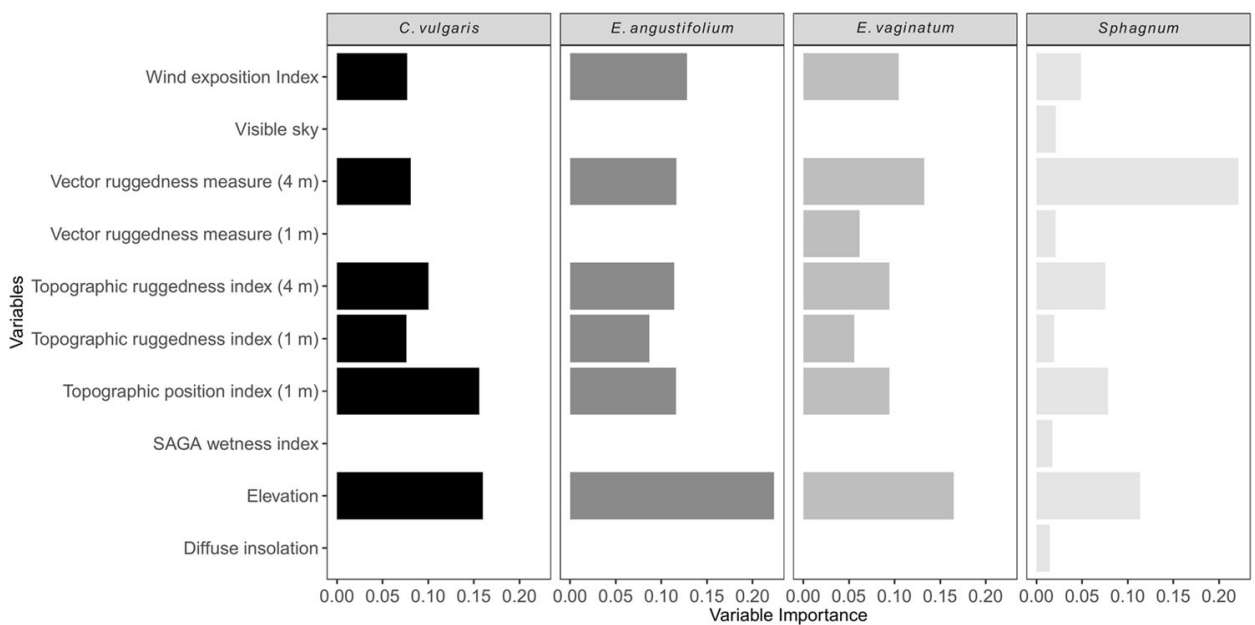

Figure 8. Variable importance based on mean decrease in model accuracy. The higher the value, the more important the variable is to the model

Positive values on the $y$-axis mean that the occurrence of a species is more likely for that value of the independent variable ( $x$ axis) and vice versa. A value of zero on the $y$-axis implies no average impact on the probability of species occurrence. In the following sections, we describe the explanatory 

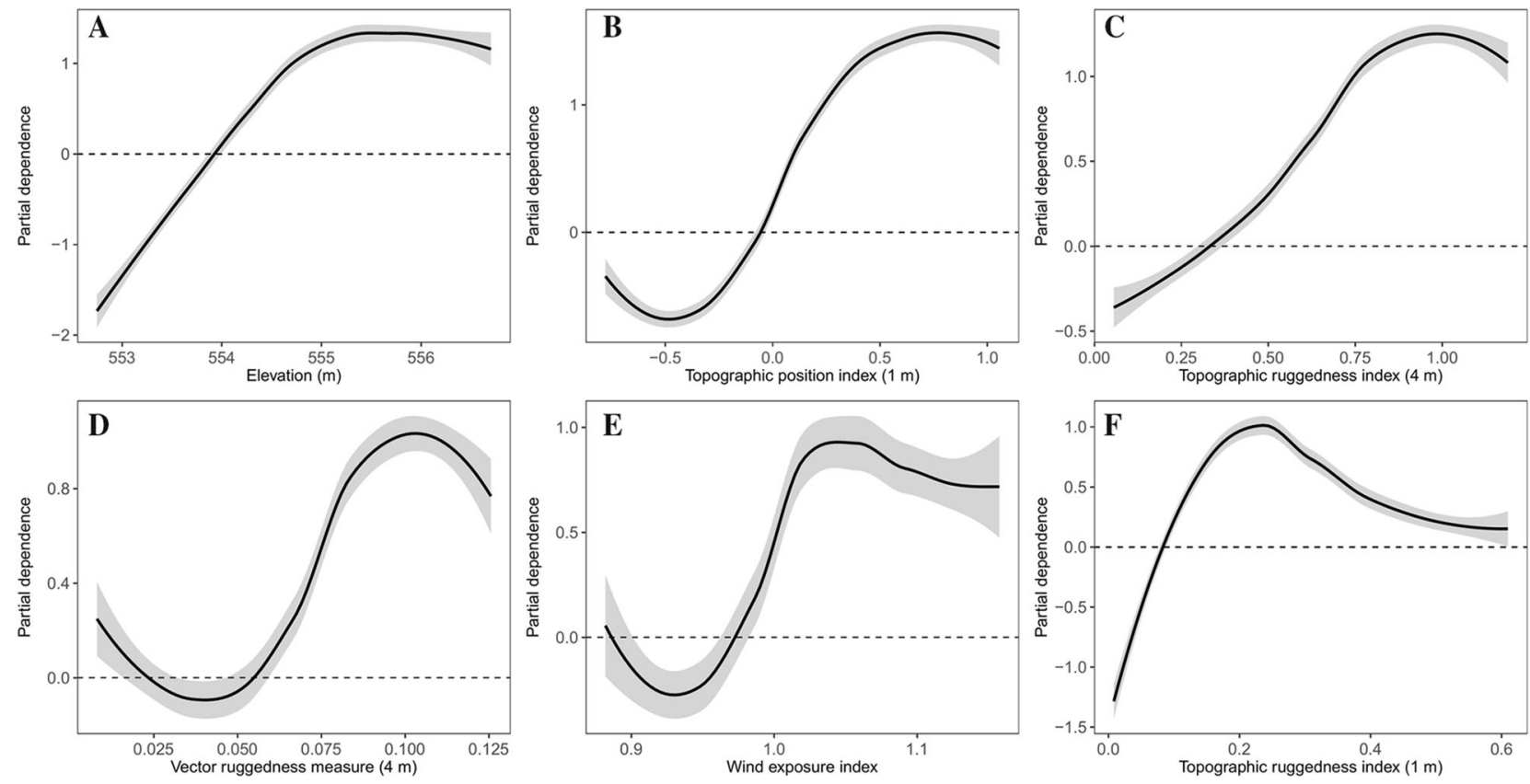

Figure 9. Partial dependence plots for each explanatory variable in order of importance (A-F) for the $C$. vulgaris model. The $y$-axis has a log scale [the logit function gives the log-odds, or the logarithm of the odds $p /(1-p)]$. The shaded area represents the $95 \%$ confidence interval of the smoothed curve. The dotted line of zero average impact is plotted to aid interpretation
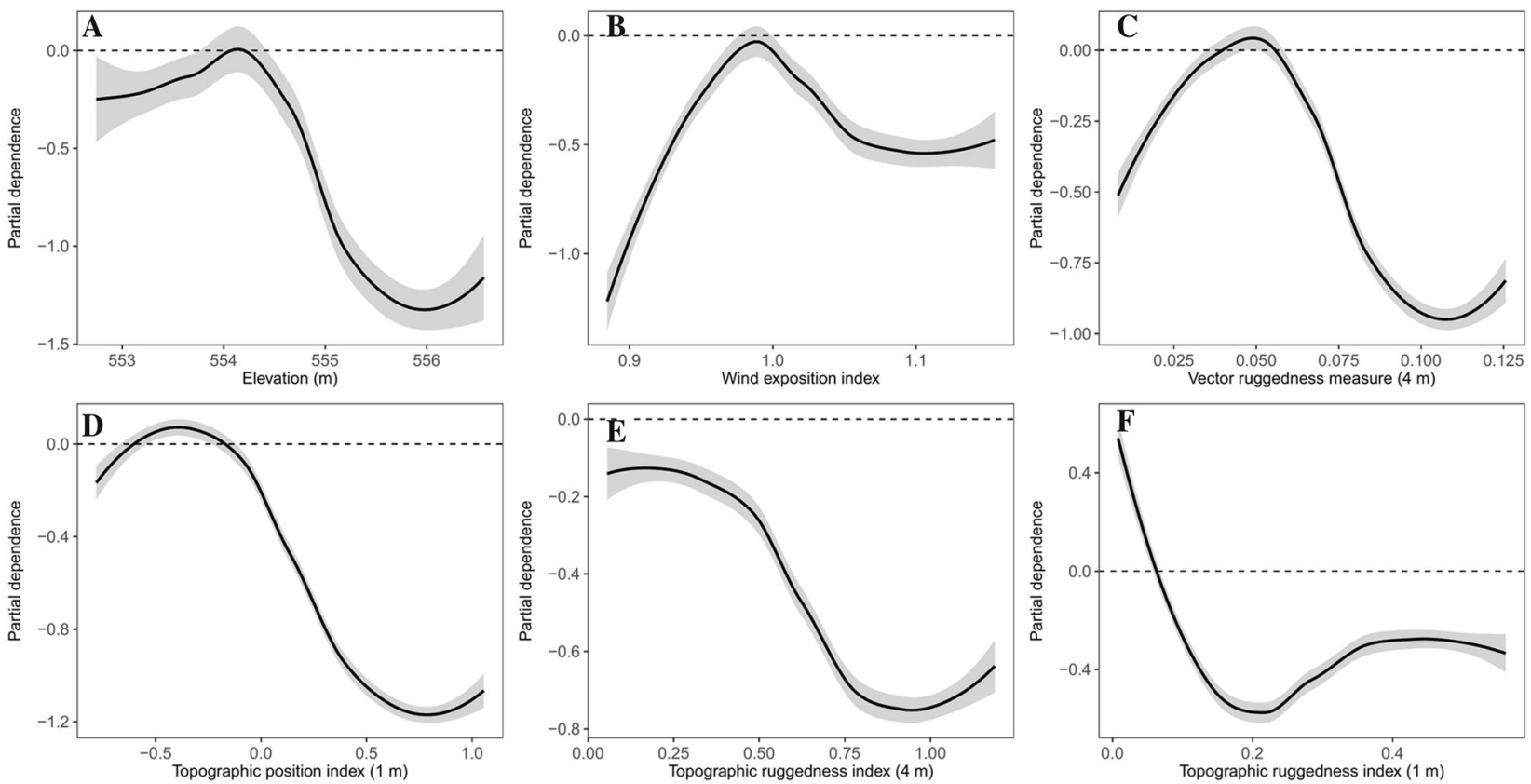

Figure 10. Partial dependence plots for each explanatory variable in order of importance (A-F) for the E. angustifolium model

variables, their rankings, and their partial dependence plots, within the context of each species/group studied.

\section{Calluna vulgaris}

Elevation, topographic position, ruggedness, and wind exposure were the most important predictors 

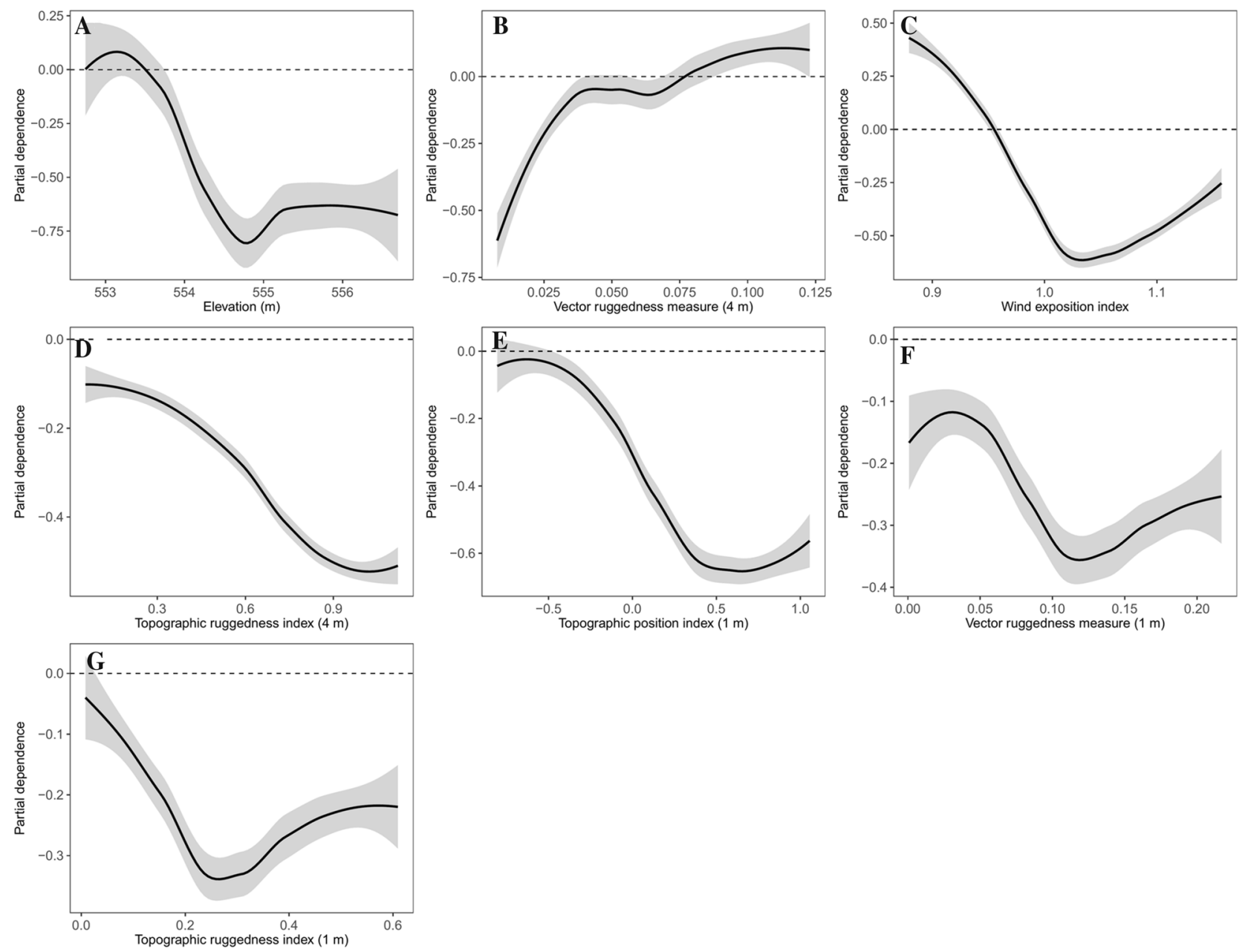

Figure 11. Partial dependence plots for each explanatory variable in order of importance (A-G) for the E. vaginatum model

of C. vulgaris (Figure 8). The PDPs show that the relationship between the probability of occurrence and all variables was generally positive but nonlinear, often increasing towards an asymptote before decreasing (Figure 9). The probability of occurrence of $C$. vulgaris initially increased with elevation (Figure 9A) and with increasing topographic position index (TPI; Table 2), suggesting that this species is associated with higher elevations and locations where the surrounding (i.e. $1 \mathrm{~m}$ radius) terrain is lower, for example, ridges or hummocks (Figure 9B). The wind exposure index (WEI; Table 2) PDP plot (Figure 9E) suggests that C. vulgaris is more likely to occur in areas exposed to the wind, than in wind-shadows, although the probability of occurrence decreased as the WEI increased above 1.05, suggesting a limit to the tolerated level of wind exposure. Variables that measured ruggedness or surface heterogeneity were also important predictors of C. vulgaris (Figure 9C-F).
Surface heterogeneity was positively correlated with the probability of species occurrence at all but the most heterogeneous locations (Figure 9C, D). At the more localised scale, the surface immediately surrounding the plant was likely to be more homogenous (Figure 9F). The model's spatial predictions confirmed this interpretation and predicted many high presence probability patches of C. vulgaris along the elevated margins of the hagged area and on the haggs (Figure 7A).

\section{Eriophorum angustifolium}

Elevation, wind exposure, topographic position, and ruggedness were also the most important predictors of E. angustifolium (Figure 8), although the relationships with each variable were often the opposite for those found for C. vulgaris (Figure 10). In general, the probability of $E$. angustifolium occurrence decreased as elevation, ruggedness, and topographic position increased (Figure 10A, C, D, 

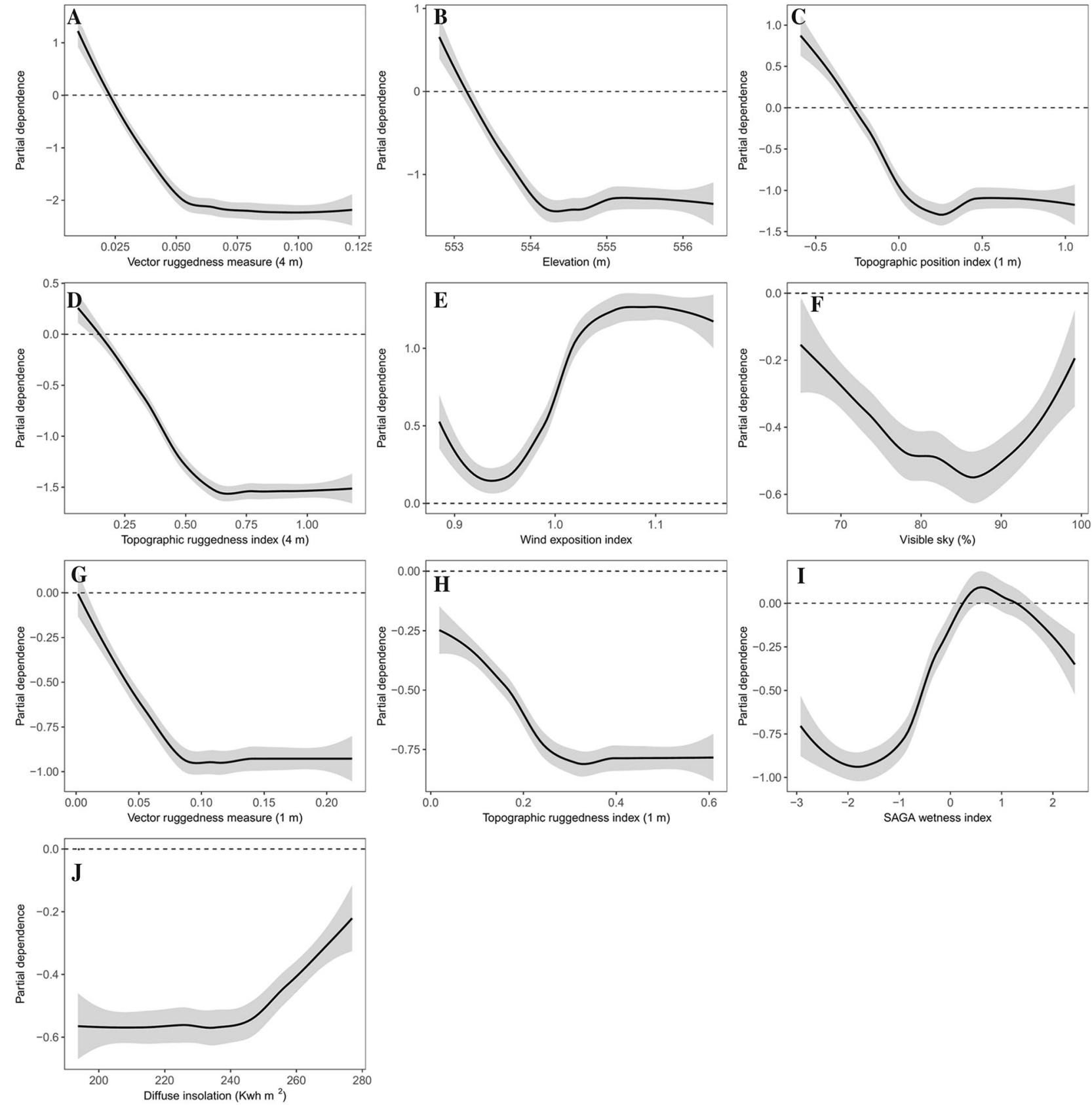

Figure 12. Partial dependence plots for each explanatory variable in order of importance (A-J) for the Sphagnum model

E, and F). E. angustifolium was also less likely to occur in very sheltered or extremely exposed locations (Figure 10B). Spatial predictions of the probability of species presence showed E. angustifolium to be most likely to occur in the flat gullied regions between the haggs and in some of the minor depressions, which form at the outer limits of the hagged area (Figure 7B). There were also areas that are currently bare peat where the spatial model predicted the presence of E. angustifolium.

\section{Eriophorum vaginatum}

Elevation, ruggedness, wind exposure, and topographic position were the most important predictors of the probability of $E$. vaginatum presence 
(Figure 8). The elevation PDP of the probability of E. vaginatum occurrence showed a slightly positive relationship up to approximately $553 \mathrm{~m}$ but then decreased sharply (Figure 11A). E. vaginatum was most likely to be found in areas sheltered from the wind (Figure 11C) and least likely to be found in topographically exposed sites (Figure 11E). In general, the surface ruggedness PDPs suggested that topography within the immediate and surrounding vicinity of the vegetation was likely to be relatively flat (Figure 11D, F and G). The only exception was the PDP plot of the vector ruggedness measure (VRM4; Table 2 and Figure 11B) which showed a positive relationship between probability of presence and ruggedness, although the values of VRM4 were very small, suggesting that the model was influenced by small increases in heterogeneity that occurred within a homogenous terrain (i.e. VRM $<0.15)$. The spatial predictions made by the model indicated that $E$. vaginatum was most likely to occur in flat gullied areas and on the bases of the haggs (Figure 7). Like the E. augustifolium model, there were several areas where the spatial model predicted the presence of $E$. vaginatum that are currently bare peat.

\section{Sphagnum}

The Sphagnum model contained the highest number of morphometric and topographic variables. The five most influential explanatory variables were similar to those of the other three species models, although two light-related variables and a wetness index were also selected (Figure 8). The probability of Sphagnum presence dropped rapidly with increased ruggedness, elevation, and topographic position before levelling off (Figure 12A, B, $D, G$, and $H$ ). Low levels of diffuse radiation and drier conditions (low values of the SAGA wetness index (SWI); Table 2) both negatively influenced Sphagnum presence (Figure 12I, J), although very wet conditions (high values of SWI) also reduced the probability of Sphagnum occurrence (Figure 12J). Sphagnum was least likely to occur in areas where solar radiation may be moderate to high (i.e. VIS (visible sky) $80-90 \%$ ), although the influence of VIS on predicting Sphagnum reduced (i.e. partial dependence tended towards zero) as VIS increased or decreased beyond this range (Figure 12F). The spatial predictions (Figure 7) show high probabilities of Sphagnum presence are predicted to be confined to some of the lower elevations along the western side of the hagged area and for some areas currently occupied by E. vaginatum. Sphagnum was not frequently predicted to occur on the exposed bare peat in the central and eastern areas of the region.

\section{Discussion}

The overarching goal of this study was to determine whether morphological and topographic variables, derived from a fine-scale DSM, can improve our knowledge and understanding of the patterns of revegetation in naturally eroding blanket peatlands.

Elevation models based on remotely sensed data have previously been used in peatland research, with applications of topographic data ranging from delineating and identifying wetlands and peatlands within the wider ecological landscape (for example, Chasmer and others 2016; Hird and others 2017; O'Neil and others 2018) to mapping watertable depths (Rahman and others 2017) and microtopography (Lovitt and others 2017) within an individual peatland. However, our results present the first demonstration that drone-based elevation data can be used as an exploratory tool for understanding processes governing natural patterns of peatland revegetation in eroding landscapes. The amount of topographic data that can be obtained from drone imagery far surpasses what was collected in previous ground-based peatland morphological studies (for example, Evans and others 2005; Pouliot and others 2011; Malhotra and others 2016). Our approach, which models topographic-species relationships, has the added advantage of providing spatially explicit predictions of species occurrence, as opposed to mapping current distribution (for example, Knoth and others 2013; Lehmann and others 2016). Comparisons between where a species is predicted as likely to occur and where it currently occurs can help understanding of future change trajectories. The above-ground predictions of species occurrence can also be validated using follow-up drone surveys.

All four models generated using the random forest procedure showed high accuracy, recall, precision, and AUC scores, indicating reliable prediction performance. Despite the inclusion of a large number of different morphometric and topographic variables, fewer than half of the variables were consistently selected by the models. The most important variable was often elevation (mean within a $1 \mathrm{~m}$ radius), followed by variables related to the topographic position within the hagged area, the degree of exposure of the surface to the wind, and the heterogeneity or ruggedness of the surrounding surface. The consistent and substantial influence of a small number of variables highlights 
their importance in controlling species distributions. Morphology and topography are likely to have an important influence on species presence within a peatland because of the close relationships that exist between vegetation, topography, and moisture regime (for example, Bubier and others 2006; Malhotra and others 2016). In non-eroding peatlands, microtopography occurs because of differing rates of net peat accumulation (Nungesser 2003), and nonlinear interactions between moisture regimes and vegetation production result in long-term evolution of microtopography (Belyea and Clymo 2001; Eppinga and others 2009; Morris and others 2013). Whilst the microtopography of the Upper Conwy is a result of a long history of erosion (Ellis and Tallis 2001) rather than differences in net peat accumulation, in terms of hydrology, microforms on eroding and non-eroding peatlands are likely to be broadly similar. Surprisingly, the morphometric variable specifically designed to represent changes in moisture (for example, SWI) was only chosen by the Sphagnum model. It is unlikely that moisture is not a primary driver of species presence more generally and its relative absence suggests that other morphometric and topographic variables provided a better representation of hydrological conditions in this locality.

Although the ecology of many key peatland species is already well described (Rydin and Jeglum 2006) and correlates well with the most important variables identified by our models, the partial dependence plots revealed spatial associations and quantified the distribution of each species in relation to local $(10 \mathrm{~s} \mathrm{~m})$ and landscape-scale $(100 \mathrm{~s}-$ $1000 \mathrm{~s} \mathrm{~m})$ environmental factors. C. vulgaris, $E$. angustifolium, and Sphagnum were the species most successfully modelled, according to the OOB accuracy measure. The $C$. vulgaris model identified elevation as one of the most important predictors of species presence in the eroded landscape. Overall, elevation had a positive effect on the probability of occurrence. C. vulgaris is a common species in ombrotrophic peatlands and is known to be generally intolerant of water logging (Bragazza and Gerdol 1996). Previous studies have also shown that $C$. vulgaris abundance is often greater on drier parts of the microtopography, namely hummocks and high lawns (for example, Laine and others 2007). Similarly, Wallèn (1987) recorded no above-ground evidence of $C$. vulgaris within the zone where the ground surface was within $3 \mathrm{~cm}$ of the maximum water level on a raised bog in south Sweden. We did not measure water-table position, but those parts of the terrain with higher relative elevations can be expected to have the deepest water tables and vice versa. Although the overall relationships between the probability of $C$. vulgaris presence and elevation were positive, the beginnings of a negative relationship were observed at the highest elevations. Similar switches between positive and negative relationships were observed in the other selected explanatory variables, suggesting that $C$. vulgaris is less likely to occur at the highest, most exposed, and most heterogeneous locations than it is in more topographically moderate settings. Several other studies have reported similar findings in relation to elevation. For example, Wallèn (1988) reported C. vulgaris biomass to be highest at microsites a few $\mathrm{cm}$ lower than the highest and driest parts of the microtopography, whilst, for a greater water-table range ( $70 \mathrm{~cm})$, Bragazza and Gerdol (1996) noted that C. vulgaris cover increased but then decreased as depth to the water-table increased, with this relationship being mediated by pore-water $\mathrm{pH}$.

Both Eriophorum models predicted Eriophorum presence on what is currently bare peat (Figures 7 and 3). Given that vegetation distribution is a result of both environmental conditions and ecological processes, the relative importance of which is hard to capture, our spatial model predictions should be interpreted as habitat suitability maps. Many of the $E$. angustifolium presence predictions were of high probability, suggesting that these locations were particularly suitable for Eriophorum growth. The lack of Eriophorum at these locations may not indicate an incorrect model prediction but simply suggest that insufficient time has passed for Eriophorum to colonise these areas. Figure 13 shows evidence of large patches of $E$. angustifolium spreading across depositional flats at the field site,

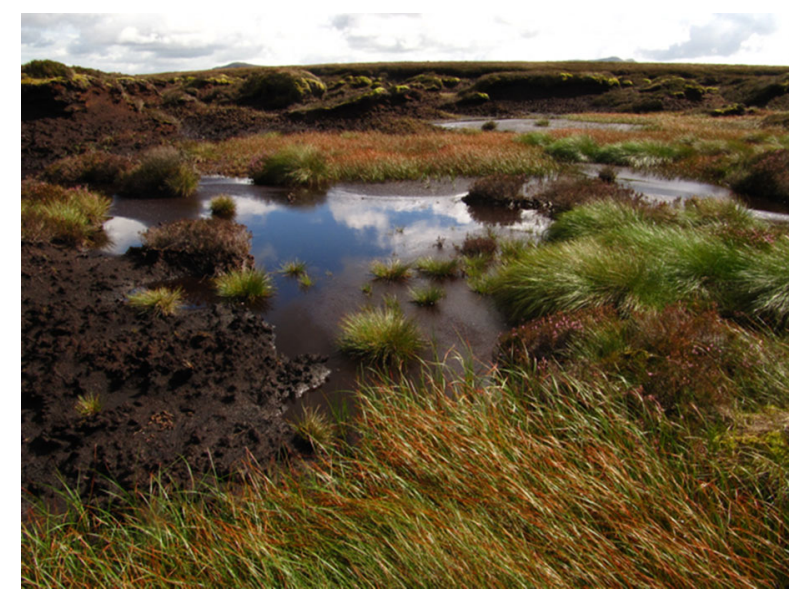

Figure 13. E. angustifolium and E. vaginatum growing on peat flats. Repeat visits to the study site suggest that both species are spreading across the flats 
and anecdotal evidence indicates an expansion of E. angustifolium in these areas since 2010. The predicted and observed recolonisation of bare peat by Eriophorum is similar to previous observations made in disturbed peatlands (Lavoie and others 2005) and more generally in studies of peatland formation and succession (for example, Hughes and Dumayne-Peaty 2002; Dudova and others 2013; Tuittila and others 2013). The success of Eriophorum establishment and survival in degraded peatlands can be attributed to both its deep root system (Shaver and Billings 1977), which can tolerate long periods of drought (Buttler and others 2015), and the effective dispersal of its seeds by wind (Campbell and others 2003). For example, Lavoie and others (2005) observed the rapid colonisation of E. vaginatum in an abandoned vacuum-mined Canadian bog following measures to increase the water-table level and peat moisture content. Rapid expansion of $E$. vaginatum often occurs when the water table is less than $40 \mathrm{~cm}$ below the peat surface (Komulainen and others 1998; Tuittila and others 2000). Below this threshold, Eriophorum tussocks are likely to form but growth and expansion are likely to be slower (Lavoie and others 2005). The orthomosaic of the Migneint erosion complex suggests that $E$. vaginatum can establish from seed and subsequently form tussocks on areas of bare peat. E. vaginatum appears to be spreading into the bare peat areas from areas of high abundance in the north (north-west) of the study area (Figure 3A). E. angustifolium is less frequently cited as a pioneer coloniser of bare peat. However, plant macrofossil records obtained from a UK eroded blanket peatland have revealed that revegetation in gullied regions was often initiated by E. angustifolium (Crowe and others 2008). More recently, E. angustifolium has been observed as one of the first colonisers of more nutrient-rich portions of a restored Swedish bog (Kozlov and others 2016).

The probability of occurrence predictions made by the Sphagnum model indicates that Sphagnum mosses in the hagged portion of the peatland are most likely to occur at relatively wet and comparatively low elevations and topographic positions. The Sphagnum models were for S. cuspidatum and S. fallax in combination, and both are known to occur in wetter parts of a bog surface (Bragazza and Gerdol 1996). S. fallax does not grow well in completely submerged conditions, whereas S. cuspidatum grows well in pools, which may explain the observed hump-shaped relationship with wetness observed in the PDP. The modelling results also suggest that available light or the level of shadowing may be an important predictor of Sphagnum. Increases in diffuse light increased the probability of Sphagnum occurrence, whereas increases in visible sky initially decreased the probability of Sphagnum occurrence until a point beyond which the influence of light began to weaken. Diffuse radiation has much less tendency to cause canopy photosynthetic saturation than direct radiation as the light is more evenly distributed amongst leaves in the plant canopy (Gu and others 2002) and thus may be advantageous for Sphagnum growth. In contrast, locations that have a high percentage of visible sky overhead are likely to be more exposed and thus susceptible to higher levels of direct radiation. Increased radiation is often accompanied by higher surface temperatures and increased desiccation, both of which may have a negative influence on Sphagnum establishment and growth (Murray and others 1993; Green and others 2017). It is not entirely clear why predicted probability of Sphagnum occurrence begins to increase as visible sky levels increase above $85 \%$, but it could be related to the differences in species tolerance to microclimate and thus their location within the peatland. For example, whilst $S$. fallax is commonly found in wet locations, previous studies have shown that it is able to survive in drier locations (Wagner and Titus, 1984) and thus recolonise areas of bare or dried-out peat (Grosvernier and others 1997; Buttler and others 2015), which are often exposed and susceptible to higher levels of light exposure.

The influence of light and water on Sphagnum growth has previously been studied (for example, Hayward and Clymo 1983; Gerdol and others 1996; Grosvernier and others 1997; Bonnett and others Bonnett et al. 2010), but often in isolation or under experimental conditions. Such knowledge has not been used to simulate where Sphagnum is likely to grow or be absent in a topographically complex peatland. Our spatial predictions somewhat overpredict current Sphagnum occurrence but suggest that habitats currently occupied by E. vaginatum are suitable for Sphagnum growth (Figures 7 and 3). Several studies have reported evidence that Sphagnum regrowth in degraded bogs is often accompanied by the presence of Eriophorum (Buttler and others 1996; Hughes and Dumayne-Peaty 2002). Eriophorum is thought to create a suitable microclimatic for Sphagnum growth (Grosvernier and others 1995; Tuittila and others 2000). Field observations indicate that Sphagnum is currently colonising stands of $E$. vaginatum within the Migneint study area (Figures 2 and 7).

Whilst our spatial model predictions are necessarily site specific, the morphological/topographic relationships with species presence, identified for 
the Migneint peatland, may be applicable to other erosion sites and of use to other researchers. As noted in "Methodology", the site is similar to many other UK hagged peatlands. A better understanding of the microtopographic drivers of vegetation patterning in eroding peatlands is also import for effective peatland management. Although our methodological approach results in predictive models that are inherently static in nature, both the contemporary vegetation status and variability are represented; thus, a baseline model can be created. If the relationships between the most important predictive variables and species occurrence are understood, the models can subsequently be used for monitoring purposes (Alexander and others 2016). For example, any observed changes in the relationship between elevation and species occurrence, in comparison with the baseline model, may provide an indication of changes in the underlying hydrology or microclimate, which could further be investigated. Active restoration is another important objective for the management of many degraded peatlands. However, restoration approaches, which commonly involve damming gullies and installing barriers to flow, can be very expensive. Our modelling approach, which can identify those circumstances under which peatlands are likely to self-restore successfully without management intervention, would clearly be a useful and cost-effective management tool.

\section{ConClusion}

We used topographic and morphometric variables derived from a high-spatial-resolution DSM to investigate microtopographic controls on vegetation patterning in a blanket peatland recovering from erosion. To our knowledge, this study is the first of its kind to use a fine-scale topographic model to explore the wide range of factors thought to influence revegetation in eroded blanket peatlands. RF models accurately predicted the occurrence of four common peatland species (Calluna vulgaris, Eriophorum vaginatum, Eriophorum angustifolium, and Sphagnum spp.), which represented three important plant functional types. The models used relatively few variables, thus confirming the importance of microtopography in controlling peatland species distributions. Elevation, topographic position, wind exposure, and the heterogeneity or ruggedness of the surrounding surface were key variables identified in all species models, whereas light-related variables and a wetness index were important in the Sphagnum model. The outputs from our RF models provided very-fine-scale predictions of habitat suitability and thus where species were likely to establish. Continued monitoring of the topography and morphology of selfrestoring peatlands and their evolving relationship with species composition will improve our knowledge of the mechanisms involved in revegetation by validating our model predictions. Our novel approach can be used to not only improve upon predictions of future responses and sensitivities of peatland recovery to climatic changes but also as a cost-effective management tool to identify areas of blanket peatlands that may self-restore successfully without intervention.

\section{ACKNOWLEDGEMENTS}

The National Trust (Wales) is thanked for providing permission to work at the study site and for providing LiDAR data; in particular, we appreciate the efforts of Trystan Edwards and Andrew Roberts to promote research work at the site. Dr Sheila Palmer, formerly of the University of Leeds, provided useful criticisms of our original ideas at the outset of the project. We thank the editor Nigel Roulet and two anonymous reviewers for their helpful comments on an earlier version of the paper.

\section{OPEN ACCESS}

This article is distributed under the terms of the Creative Commons Attribution 4.0 International License (http://creativecommons.org/licenses/by/4 $.0 /$ ), which permits unrestricted use, distribution, and reproduction in any medium, provided you give appropriate credit to the original author(s) and the source, provide a link to the Creative Commons license, and indicate if changes were made.

\section{REFERENCES}

Aiton W. 1882. Treatise on the origin, qualities, and cultivation of moss earth, cited in Munro R. Ancient Scottish Lake Dwellings or Crannogs.

Alexander C, Deák B, Heilmeier H. 2016. Micro-topography driven vegetation patterns in open mosaic landscapes. Ecol Indic 60:906-20.

Baird AL, Holden J, Chapman P. 2009. Literature review of evidence of emissions of methane in peatlands. Unpublished report to Defra under Grant SP0574, 54 pp, downloadable from randd.defra.gov.uk/Document.aspx?Document=S P0574_8526_FRP.pdf.

Belyea LR, Clymo R. 2001. Feedback control of the rate of peat formation. Proc R Soc London B Biol Sci 268:1315-21.

Bivand R, Piras G. 2015. Comparing implementations of estimation methods for spatial econometrics. J Stat Softw 63:136. 
Böhner J, Antonic O. 2009. Land-surface parameters specific to topo-climatology. In: Hengl T, Reuter HI, Eds. Geomorphometry: Concepts, software, applicationsp 195-226.

Böhner J, Koethe R, Conrad O, Gross J, Ringeler A, Selige T. 2002. Soil regionalisation by means of terrain analysis and process parameterisation. In: Micheli E, Nachtergaele F, Montanarella L, Eds. Soil Classification 2001. Luxembourg: European Soil Bureau. p 213-22.

Bonnett SAF, Ostle N, Freeman C. 2010. Short-term effect of deep shade and enhanced nitrogen supply on Sphagnum Capillifolium morphophysiology. Plant Ecol 207:347-58.

Bower MM. 1962. A review of evidence in the light of recent work in the pennines. Scottish Geogr Mag 78:33-43.

Bowler M, Bradshaw R. 1985. Recent accumulations and erosion of blanket peat in the Wicklow mountains, Ireland. New Phytol 101:543-50.

Bragazza L, Gerdol R. 1996. Response surfaces of plant species along water-table depth and PH gradients in a poor mire on The Southern Alps (Italy). Ann Botanici Fennici 33:11-20.

Bragg OM, Tallis JH. 2001. The sensitivity of peat-covered upland landscapes. CATENA 42:345-60.

Breiman L. 2001. Random forests. Mach learn 45:5-32.

Brenning A. 2008. Statistical geocomputing combining R and SAGA: The example of landslide susceptibility analysis with generalized additive models. In: Boehner J, Blaschke $\mathrm{T}$, Montanarella L, Eds. Saga—seconds out. Hamburger: Beiträge zur Physischen Geographie und Landschaftsökologie. p 23-32.

Buechling A, Tobalske C. 2011. Predictive habitat modeling of rare plant species in pacific northwest forests. Western J Appl For 26:71-81.

Buttler A, Robroek BJM, Laggoun-Defarge F, Jassey VEJ, Pochelon C, Bernard G, Delarue F, Gogo S, Mariotte P, Mitchell EAD, Bragazza L. 2015. Experimental warming interacts with soil moisture to discriminate plant responses in an ombrotrophic peatland. J Veg Sci 26:964-74.

Buttler A, Warner BG, Grosvernier P, Matthey Y. 1996. Vertical patterns of testate amoebae (Protozoa: Rhizopoda) and peatforming vegetation on cutover bogs in the Jura, Switzerland. New Phytol 134:371-82.

Campbell DR, Rochefort L, Lavoie C. 2003. Determining the immigration potential of plants colonizing disturbed environments: The case of milled peatlands in Quebec. J Appl Ecol 40:78-91.

Chapman DS, Bonn A, Kunin WE, Cornell SJ. 2010. Random forest characterization of upland vegetation and management burning from aerial imagery. J Biogeogr 37:37-46.

Chasmer L, Hopkinson C, Montgomery J, Petrone R. 2016. A physically based terrain morphology and vegetation structural classification for wetlands of the boreal plains, Alberta, Canada. Can J Remote Sens 42:521-40.

Clement S. 2005. The future stability of upland blanket peat following historical erosion and recent re-vegetation. Durham: Durham University.

Crowe, S., Evans, M., Allott, T., 2008. Geomorphological controls on the re-vegetation of erosion gullies in blanket peat: Implications for bog restoration. Mires \& Peat 3.

Cutler DR, Edwards TC, Beard KH, Cutler A, Hess KT, Gibson J, Lawler JJ. 2007. Random forests for classification in ecology. Ecology 88:2783-92.

Dudova L, Hajkova P, Buchtova H, Opravilova V. 2013. Formation, succession and landscape history of central-European summit raised bogs: A multiproxy study from the Hruby Jesenik mountains. Holocene 23:230-42.

Ellis CJ, Tallis JH. 2001. Climatic control of peat erosion in a North Wales blanket mire. New Phytol 152:313-24.

Eppinga MB, de Ruiter PC, Wassen MJ, Rietkerk M. 2009. Nutrients and hydrology indicate the driving mechanisms of peatland surface patterning. The American Nat 173:803-18.

Evans, J., Murphy, M., 2016. Rfutilities. R package version 2.00 .

Evans JS, Cushman SA. 2009. Gradient modeling of conifer species using random forests. Landsc Ecol 24:673-83.

Evans M, Allott T, Crowe S, Liddaman L. 2005. Feasible locations for gully blocking. In: Holden J, Flitcroft C, Bonn A, Eds. Understanding gully blocking in deep peat. Casleton, UK: Moors for the Future. p 27-76.

Evans M, Warburton J. 2005. Sediment budget for an eroding peat-moorland catchment in northern England. Earth Surface Process Landforms 30:557-77.

Evans M, Warburton J. 2007. Geomorphology of upland peat: Erosion, form and landscape change. London: Wiley.

Foulds SA, Warburton J. 2007. Significance of wind-driven rain (wind-splash) in the erosion of blanket peat. Geomorphology 83:183-92.

Gallego-Sala AV, Charman DJ, Harrison SP, Li G, Prentice IC. 2016. Climate-driven expansion of blanket bogs in Britain during the Holocene. Climate Past 12:129-36.

Gallego-Sala AV, Prentice IC. 2013. Blanket peat biome endangered by climate change. Nat Climate Change 3:152-5.

Gerdol R, Bonora A, Gualandri R, Pancaldi S. 1996. CO 2 exchange, photosynthetic pigment composition, and cell ultrastructure of sphagnum mosses during dehydration and subsequent rehydration. Can J Bot 74:726-34.

Green SM, Baird AJ, Holden J, Reed D, Birch K, Jones P. 2017. An experimental study on the response of blanket bog vegetation and water tables to ditch blocking. Wetlands Ecol Manag 25:703-16.

Grosvernier P, Matthey Y, Buttler A. 1995. Microclimate and physical properties of peat: New clues to the understanding of bog restoration processes. Vitenskapsmuseet Rappoer Botanisk Serie: Universitetet I Trondheim. p 1994.

Grosvernier P, Matthey Y, Buttler A. 1997. Growth potential of three Sphagnum species in relation to water table level and peat properties with implications for their restoration in cutover bogs. J Appl Ecol 34:471-83.

Gu LH, Baldocchi D, Verma SB, Black TA, Vesala T, Falge EM, Dowty PR. 2002. Advantages of diffuse radiation for terrestrial ecosystem productivity. J Geophys Res Atmospheres 107(D6):ACL-2.

Guisan A, Weiss SB, Weiss AD. 1999. Glm versus cca spatial modeling of plant species distribution. Plant Ecol 143:107-22.

Harrell Jr, F.E., 2016. Rms: Regression modeling strategies. R package version 4.5-0. City

Hayward PM, Clymo RS. 1983. The growth of sphagnum: Experiments on, and simulation of, some effects of light flux and water-table depth. J Ecol 71:845-63.

Hijmans, R.J., 2016. Raster: Geographic data analysis and modeling. $\mathrm{R}$ package version $2.5-8$

Hird, J.N., DeLancey, E.R., McDermid, G.J., Kariyeva, J., 2017. Google Earth Engine, open-access satellite data, and machine learning in support of large-area probabilistic wetland mapping. Remote Sensing 9. 
Höhle J, Höhle M. 2009. Accuracy assessment of digital elevation models by means of robust statistical methods. ISPRS J Photogrammetry Remote Sensing 64:398-406.

Hughes PDM, Dumayne-Peaty L. 2002. Testing theories of mire development using multiple successions at Crymlyn Bog, West Glamorgan, South Wales, UK. J Ecol 90:456-71.

Komulainen VM, Nykanen H, Martikainen PJ, Laine J. 1998. Short-term effect of restoration on vegetation change and methane emissions from peatlands drained for forestry in southern Finland. Can J For Res Revue Canadienne De Recherche Forestiere 28:402-11.

Kozlov, S.A., Lundin, L., Avetov, N.A., 2016. Revegetation dynamics after 15 years of rewetting in two extracted peatlands in Sweden. Mires and Peat 18.

Knoth C, Klein B, Prinz T, Kleinebecker T. 2013. Unmanned aerial vehicles as innovative remote sensing platforms for high-resolution infrared imagery to support restoration monitoring in cut-over bogs. Appl Veg Sci 16:509-17.

Kuhn, M., Wing, J., Weston, S., Williams, A., Keefer, C., Engelhardt, A., Cooper, T., Mayer, Z., Kenkel, B., 2015. Caret: Classification and regression training. $\mathrm{R}$ package version 6.071. CRAN, Vienna, Austria

Kumar L, Skidmore AK, Knowles E. 1997. Modelling topographic variation in solar radiation in a GIS environment. Int $\mathrm{J}$ Geogr Inf Sci 1 1:475-97.

Laine A, Byrne KA, Kiely G, Tuittila ES. 2007. Patterns in vegetation and $\mathrm{CO} 2$ dynamics along a water level gradient in a lowland blanket bog. Ecosystems 10:890-905.

Lavoie C, Marcoux K, Saint-Louis A, Price JS. 2005. The dynamics of a cotton-grass (Eriophorum vaginatum l.) cover expansion in a vacuum-mined peatland, southern Quebec. Canada. Wetlands 25:64-75.

Lawson IT, Church MJ, Edwards KJ, Cook GT, Dugmore AJ. 2007. Peat initiation in the Faroe islands: Climate change, pedogenesis or human impact? Earth Environ Sci Trans R Soc Edinburgh 98:15-28.

Lehmann, J.R.K., Munchberger, W., Knoth, C., Blodau, C., Nieberding, F., Prinz, T., Pancotto, V.A., Kleinebecker, T., 2016. High-resolution classification of South Patagonian peat bog microforms reveals potential gaps in up-scaled $\mathrm{CH}_{4}$ fluxes by use of unmanned aerial system (UAS) and CIR imagery. Remote Sensing 8.

Liaw A, Wiener M. 2002. Classification and regression by RandomForest. R news 2:18-22.

Lindsay R. 2010. Peatbogs and Carbon: A Critical Synthesis. UK: Environmental Research Group, University of East London.

Lovitt J, Rahman M, McDermid G. 2017. Assessing the value of UAV photogrammetry for characterizing terrain in complex peatlands. Remote Sensing 9:715.

Malhotra A, Roulet NT, Wilson P, Giroux-Bougard X, Harris LI. 2016. Ecohydrological feedbacks in peatlands: An empirical test of the relationship among vegetation, microtopography and water table. Ecohydrology 9:1346-57.

Morris PJ, Baird AJ, Belyea LR. 2013. The role of hydrological transience in peatland pattern formation. Earth Surf Dyn $1: 31-66$.

Murphy MA, Evans JS, Storfer A. 2010. Quantifying bufo boreas connectivity in yellowstone national park with landscape genetics. Ecology 91:252-61.

Murray KJ, Tenhunen JD, Nowak RS. 1993. Photoinhibition as a control on photosynthesis and production of Sphagnum mosses. Oecologia 96:200-7.
Nungesser MK. 2003. Modelling microtopography in boreal peatlands: Hummocks and hollows. Ecol Model 165:175-207.

O'Neil GL, Goodall JL, Watson LT. 2018. Evaluating the potential for site-specific modification of LiDAR dem derivatives to improve environmental planning-scale wetland identification using random forest classification. J Hydrol 559:192-208.

Peters J, De Baets B, Verhoest NEC, Samson R, Degroeve S, De Becker P, Huybrechts W. 2007. Random forests as a tool for ecohydrological distribution modelling. Ecol Model 207:30418

Pouliot R, Rochefort L, Karofeld E. 2011. Initiation of microtopography in revegetated cutover peatlands. Appl Veg Sci 14:158-71.

Rahman, M.M., McDermid, G.J., Strack, M., Lovitt, J., 2017. A new method to map groundwater table in peatlands using unmanned aerial vehicles. Remote Sensing 9.

Riley, S., Degloria, S., Elliot, S.D., 1999. A terrain ruggedness index that quantifies topographic heterogeneity.

Rydin H, Jeglum JK. 2006. The biology of peatlands - peatland habitats. New York: Oxford University Press.

Shaver GR, Billings WD. 1977. Effects of daylength and temperature on root elongation in tundra graminoids. Oecologia 28:57-65.

Simpson, J.E., Wooster, M.J., Smith, T.E.L., Trivedi, M., Vernimmen, R.R.E., Dedi, R., Shakti, M., Dinata, Y., 2016. Tropical peatland burn depth and combustion heterogeneity assessed using UAV photogrammetry and airborne LiDAR. Remote Sensing 8.

Tallis J. 1998. Growth and degradation of British and Irish blanket mires. Environ Rev 6:81-122.

Tuittila ES, Juutinen S, Frolking S, Valiranta M, Laine AM, Miettinen A, Sevakivi ML, Quillet A, Merila P. 2013. Wetland chronosequence as a model of peatland development: Vegetation succession, peat and carbon accumulation. Holocene 23:25-35

Tuittila ES, Komulainen VM, Vasander H, Nykanen H, Martikainen PJ, Laine J. 2000. Methane dynamics of a restored cut-away peatland. Global Change Biol 6:569-81.

Wagner DJ, Titus JE. 1984. Comparative desiccation tolerance of two sphagnum mosses. Oecologia 62:182-7.

Wallen B. 1987. Growth-pattern and distribution of biomass of Calluna vulgaris on an ombrotrophic peat bog. Holarctic Ecol 10:73-9.

Williamson J, Rowe E, Reed D, Ruffino L, Jones P, Dolan R, Buckingham H, Norris D, Astbury S, Evans CD. 2017. Historical peat loss explains limited short-term response of drained blanket bogs to rewetting. J Environ Manag 188:27886.

Wishart D, Warburton J. 2001. An assessment of blanket mire degradation and peatland gully development in the Cheviot hills, northumberland. Scottish Geogr J 117:185-206.

Yokoyama R, Shirasawa M, Pike RJ. 2002. Visualizing topography by openness: A new application of image processing to digital elevation models. Photogrammetric Eng Remote Sensing 68:257-65.

Young DM, Baird AJ, Morris PJ, Holden J. 2017. Simulating the long-term impacts of drainage and restoration on the ecohydrology of peatlands. Water Res Res 53:6510-22.

Zevenbergen LW, Thorne CR. 1987. Quantitative-analysis of land surface-topography. Earth Surf Process Landforms 12:4756. 